\title{
Vertical profiles of nitrous acid in the nocturnal urban atmosphere of Houston, TX
}

\author{
K. W. Wong ${ }^{1}$, H.-J. Oh ${ }^{1}$, B. L. Lefer ${ }^{2}$, B. Rappenglück ${ }^{2}$, and J. Stutz ${ }^{1}$ \\ ${ }^{1}$ University of California Los Angeles, Department of Atmospheric and Oceanic Sciences, Los Angeles, CA 90095, USA \\ ${ }^{2}$ Department of Earth and Atmospheric Science, University of Houston, Houston, TX 77204-5007, USA
}

Received: 27 November 2010 - Published in Atmos. Chem. Phys. Discuss.: 10 December 2010

Revised: 22 March 2011 - Accepted: 7 April 2011 - Published: 18 April 2011

\begin{abstract}
Nitrous acid (HONO) often plays an important role in tropospheric photochemistry as a major precursor of the hydroxyl radical $(\mathrm{OH})$ in early morning hours and potentially during the day. However, the processes leading to formation of HONO and its vertical distribution at night, which can have a considerable impact on daytime ozone formation, are currently poorly characterized by observations and models. Long-path differential optical absorption spectroscopy (LP-DOAS) measurements of HONO during the 2006 TexAQS II Radical and Aerosol Measurement Project (TRAMP), near downtown Houston, TX, show nocturnal vertical profiles of $\mathrm{HONO}$, with mixing ratios of up to $2.2 \mathrm{ppb}$ near the surface and below $100 \mathrm{ppt}$ aloft. Three nighttime periods of $\mathrm{HONO}, \mathrm{NO}_{2}$ and $\mathrm{O}_{3}$ observations during TRAMP were used to perform model simulations of vertical mixing ratio profiles. By adjusting vertical mixing and $\mathrm{NO}_{\mathrm{x}}$ emissions the modeled $\mathrm{NO}_{2}$ and $\mathrm{O}_{3}$ mixing ratios showed very good agreement with the observations.

Using a simple conversion of $\mathrm{NO}_{2}$ to $\mathrm{HONO}$ on the ground, direct HONO emissions, as well as HONO loss at the ground and on aerosol, the observed HONO profiles were reproduced by the model for 1-2 and 7-8 September in the nocturnal boundary layer (NBL). The unobserved increase of $\mathrm{HONO}$ to $\mathrm{NO}_{2}$ ratio $\left(\mathrm{HONO} / \mathrm{NO}_{2}\right)$ with altitude that was simulated by the initial model runs was found to be due to HONO uptake being too small on aerosol and too large on the ground. Refined model runs, with adjusted HONO uptake coefficients, showed much better agreement of HONO and $\mathrm{HONO} / \mathrm{NO}_{2}$ for two typical nights, except during morning rush hour, when other HONO formation pathways are most
\end{abstract}

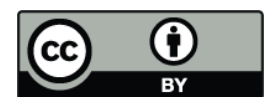

Correspondence to: J. Stutz (jochen@atmos.ucla.edu) likely active. One of the nights analyzed showed an increase of $\mathrm{HONO}$ mixing ratios together with decreasing $\mathrm{NO}_{2}$ mixing ratios that the model was unable to reproduce, most likely due to the impact of weak precipitation during this night.

HONO formation and removal rates averaged over the lowest $300 \mathrm{~m}$ of the atmosphere showed that $\mathrm{NO}_{2}$ to $\mathrm{HONO}$ conversion on the ground was the dominant source of HONO, followed by traffic emission. Aerosol did not play an important role in HONO formation. Although ground deposition was also a major removal pathway of HONO, net HONO production at the ground was the main source of HONO in our model studies. Sensitivity studies showed that in the stable NBL, net HONO production at the ground tends to increase with faster vertical mixing and stronger $\mathrm{NO}_{\mathrm{x}}$ emission. Vertical transport was found to be the dominant source of HONO aloft.

\section{Introduction}

Nitrous acid (HONO) is one of the most important hydroxyl radical $(\mathrm{OH})$ precursors in the troposphere, in particular in environments with larger $\mathrm{NO}_{\mathrm{x}}$ levels (Finlayson-Pitts and Pitts, 2000). Its photolysis (Reaction R1)

$\mathrm{HONO}+\mathrm{h} v(\lambda<400 \mathrm{~nm}) \longrightarrow \mathrm{OH}+\mathrm{NO}$

produces $\mathrm{OH}$ much earlier in the day than photolysis of $\mathrm{O}_{3}$ and formaldehyde (HCHO) (Finlayson-Pitts and Pitts, 2000). $\mathrm{HONO}$ photolysis is thus the dominant primary $\mathrm{OH}$ source in the morning. Low levels of HONO can also considerably contribute to the $\mathrm{OH}$ budget later during the day. The contribution of HONO photolysis to the total $\mathrm{OH}$ budget during the day can reach up to $34 \%$ in urban and rural environments

Published by Copernicus Publications on behalf of the European Geosciences Union. 


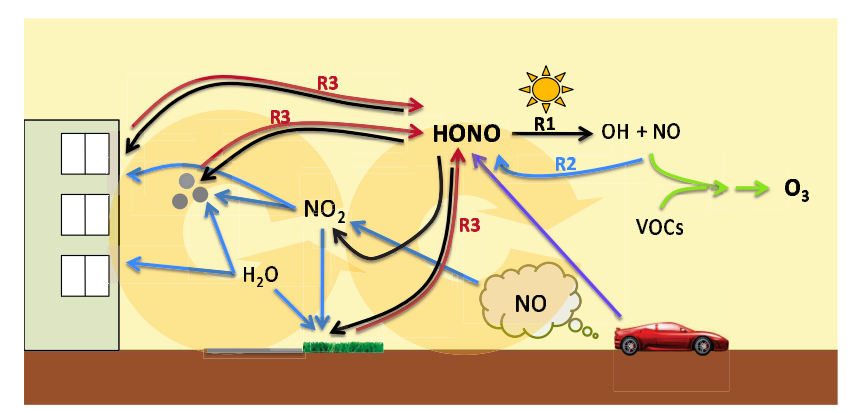

Fig. 1. Schematic figure of HONO chemistry in urban boundary layer, showing HONO formation from direct emission (purple arrow), gas-phase Reaction (R2) (cyan arrow) and heterogeneous Reaction (R3) (blue and red arrows). HONO loss processes such as photolysis (Reaction R1) and uptake on surfaces are indicated by black arrows.

(Acker et al., 2006; Kleffmann et al., 2005; Aumont et al., 2003; Alicke et al., 2002).

Despite the importance of HONO, its formation mechanism is yet not well understood. At night, when photolysis ceases, HONO mixing ratios increase gradually, reaching up to hundreds of ppt in rural areas and up to several ppb in polluted urban boundary layers (Stutz et al., 2010a; Kleffmann et al., 2006; Lammel and Cape, 1996; Platt, 1985). Different HONO formation pathways in urban areas have been identified as being important (Fig. 1). HONO is emitted directly into the atmosphere through combustion processes. Emissions depend on the type of engines and fuel, ranging from $<0.01 \%$ to $1.8 \%$ of $\mathrm{NO}_{\mathrm{x}}$ (Kurtenbach et al., 2001; Calvert et al., 1994; Pitts et al., 1984; Kessler and Platt, 1984). HONO/NO ${ }_{\mathrm{x}}$ emission ratios from traffic tunnels in California and Europe have been measured from $0.29 \%$ to $0.8 \%$ depending on the traffic density and the type of vehicles (Kurtenbach et al., 2001; Kirchstetter et al., 1996).

HONO can also be formed in gas-phase and heterogeneous chemical reactions. The most significant gas-phase reaction that leads to $\mathrm{HONO}$ formation is the reaction of $\mathrm{NO}$ with $\mathrm{OH}$.

$$
\mathrm{NO}+\mathrm{OH} \stackrel{\mathrm{M}}{\longrightarrow} \mathrm{HONO}
$$

This reaction is not significant during the night due to the low $\mathrm{OH}$ concentrations. Various other gas-phase HONO formation processes have been discussed and proposed in the past decades (Finlayson-Pitts et al., 2003; Li et al., 2008). However, none of these reactions is considered to be important at night.

It is currently believed that heterogeneous processes involving conversion of $\mathrm{NO}_{2}$ on humid surfaces are the major formation pathways of nocturnal $\mathrm{HONO}$ as described by the following stoichiometry.

$2 \mathrm{NO}_{2}(\mathrm{~g})+\mathrm{H}_{2} \mathrm{O}_{(\text {surface) }} \longrightarrow \mathrm{HONO}_{(\mathrm{g})}+\mathrm{HNO}_{3}$ (surface)
Laboratory studies show that HONO formation has a first order dependence on $\mathrm{NO}_{2}$ and depends on relative humidity (Finlayson-Pitts et al., 2003; Kleffmann et al., 2004; Lammel and Cape, 1996). Other heterogeneous reactions such as $\mathrm{NO}+\mathrm{NO}_{2}+\mathrm{H}_{2} \mathrm{O} \longrightarrow 2 \mathrm{HONO}$, reaction of $\mathrm{NO}$ and $\mathrm{HNO}_{3}$ on silica surfaces in the presence of water, heterogeneous conversion of $\mathrm{NO}_{2}$ and other reactions such as on soot surfaces appear to play only a minor role in HONO formation (Saliba et al., 2001; Calvert et al., 1994; Ammann et al., 2005; Gutzwiller et al., 2002; Arens et al., 2001; Kalberer et al., 1999; Kleffmann and Wiesen, 2005). A recent study by Ziemba et al. (2010) proposed that heterogeneous reaction of $\mathrm{HNO}_{3}$ on fresh organic aerosol can be a potentially significant source of HONO. Photoenhanced sources of HONO from reaction of $\mathrm{NO}_{2}$ on organic surfaces such as aromatic hydrocarbons and humic acids have been proposed (Stemmler et al., 2006; George et al., 2005) but will not be further discussed in this paper.

While direct emissions of HONO predominantly occur near the surface, i.e. emissions by traffic, heterogeneous conversion of $\mathrm{NO}_{2}$ to $\mathrm{HONO}$ can occur either on the ground and other surfaces such as buildings and plants, or on particles. In the former case one would expect clear vertical gradients of $\mathrm{HONO}$, in particular during the night, when mixing is inefficient. In the case of $\mathrm{NO}_{2}$ to $\mathrm{HONO}$ conversion on particles the vertical profile of HONO would follow the profile of the particles surface area, and would most likely lead to much weaker profiles. It is thus clear that the observation and interpretation of vertical concentration profiles at night can give crucial information on the nature of the surface responsible for the formation of HONO. Few attempts to use this information have been published thus far. Vertical gradients of $\mathrm{HONO}$ in the lowest $4 \mathrm{~m}$ altitude and fluxes of HONO were measured using differential optical absorption spectroscopy (DOAS) by Stutz et al. (2002) in a polluted rural area in Italy in 1998. Measurements showed that the compensation point for formation and deposition of $\mathrm{HONO}$ on grass surface occurred at $\mathrm{HONO} / \mathrm{NO}_{2}$ of $\sim 0.03$, and that emission was a significant source of HONO in polluted areas (Stutz et al., 2002). Kleffmann et al. (2003) performed HONO gradient measurements between $10-190 \mathrm{~m}$ altitudes in a semi-rural area in Germany in 2001. Their study showed that HONO formation was dominated by processes on ground surfaces and HONO formation on aerosol surfaces was insignificant (Kleffmann et al., 2003).

Knowledge of the vertical profiles of HONO is also crucial to quantify its nocturnal budget and its contribution to the $\mathrm{HO}_{\mathrm{x}}$ budget in the morning. Here we present continuous measurements of vertical concentration profiles of HONO, $\mathrm{NO}_{2}$ and $\mathrm{O}_{3}$ in Houston, TX in 2006, with a focus on nighttime data. By using a one-dimensional (1-D) chemistry and transport model, the observations will be interpreted to determine the surfaces responsible for HONO formation and to test whether simple model parameterizations of $\mathrm{NO}_{2}$ to HONO conversion can explain the observations. 


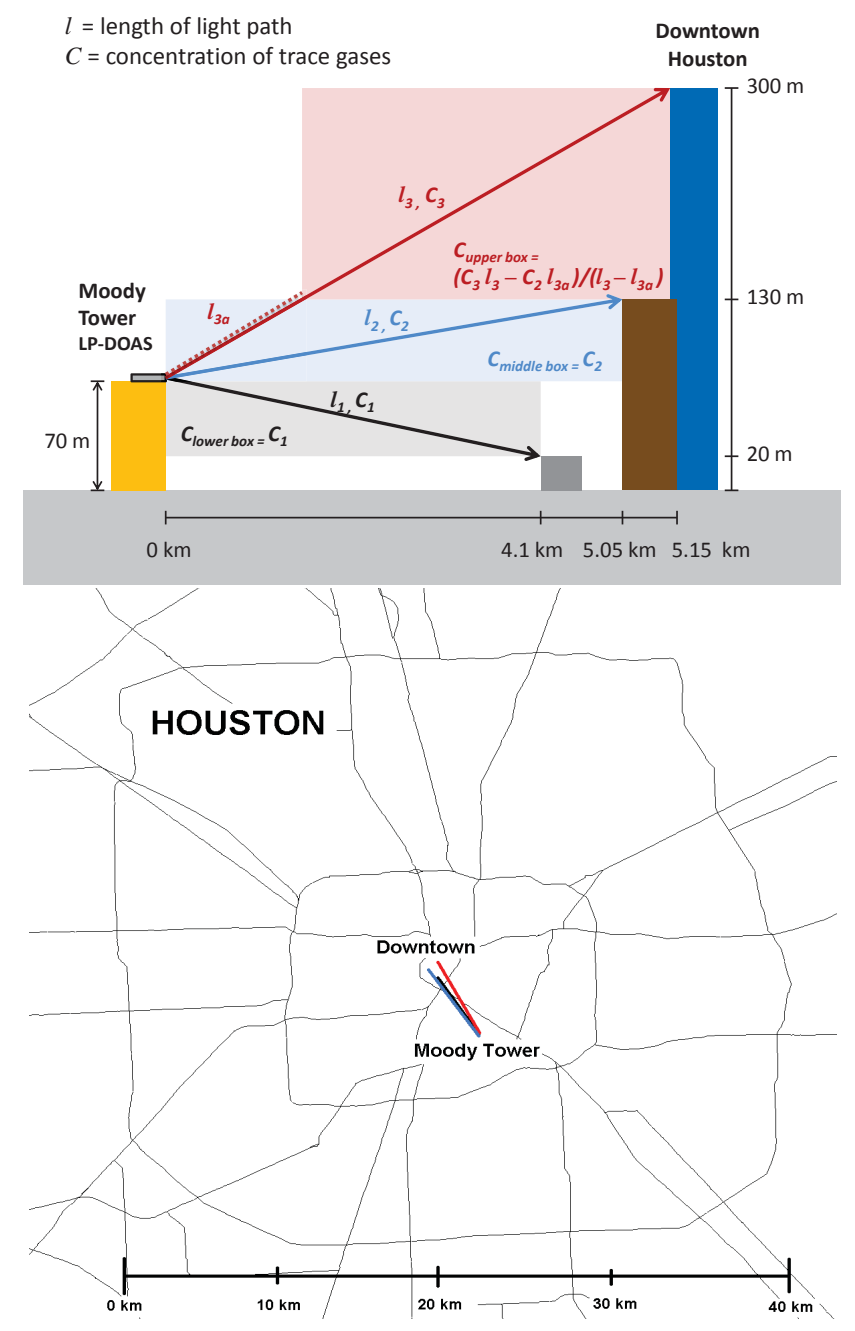

Fig. 2. Light path arrangement of the LP-DOAS systems during TRAMP 2006.

\section{Experimental}

During the Texas Air Quality Study (TexAQS) II Radical and Aerosol Measurement Project (TRAMP) in summer 2006, measurements of $\mathrm{HONO}, \mathrm{O}_{3}, \mathrm{NO}_{2}$ and other trace gases were made from 15 August to 20 September in downtown Houston, using UCLA's long-path differential optical absorption spectroscopy (LP-DOAS) instrument.

The LP-DOAS instrument was set up on the roof of the North Moody Tower on the University of Houston campus, at an altitude of about $70 \mathrm{~m}$ above the ground. The LP-DOAS instrument sent a collimated beam of light from a Xe-arc lamp through a $1.5 \mathrm{~m}$ double Newtonian telescope. Three retroreflectors were mounted on the tops of three buildings (Toyota Center, El Paso Energy Building and JP Morgan Chase Tower) located in downtown Houston at distances of $4.1 \mathrm{~km}, 5.05 \mathrm{~km}$ and $5.15 \mathrm{~km}$ from the Moody Tower at altitudes of $20 \mathrm{~m}, 130 \mathrm{~m}$ and $300 \mathrm{~m}$ respectively (Fig. 2). The
Table 1. Observed mixing ratio ranges and detection limits during TRAMP 2006.

\begin{tabular}{llll}
\hline & Mixing Ratios & $\begin{array}{l}\text { Detection Limits* } \\
\text { (Average in parenthesis) }\end{array}$ & Uncertainty \\
\hline $\mathrm{O}_{3}$ & $0-130 \mathrm{ppb}$ & $1-30 \mathrm{ppb}(2.5 \mathrm{ppb})$ & $\pm 3 \%$ \\
$\mathrm{NO}_{2}$ & $0.1-60 \mathrm{ppb}$ & $0.03-2 \mathrm{ppb}(0.12 \mathrm{ppb})$ & $\pm 5 \%$ \\
$\mathrm{HONO}$ & $0-2.15 \mathrm{ppb}$ & $0.016-0.2 \mathrm{ppb}(0.045 \mathrm{ppb})$ & $\pm 5 \%$ \\
\hline
\end{tabular}

* please note that DOAS calculates an error and detection limit for every absorption spectrum. Detection limits vary with visibility and instrument behavior.

LP-DOAS telescope aimed consecutively at these retroreflectors in order to measure the atmospheric absorptions of $\mathrm{HONO}, \mathrm{NO}_{2}$, and $\mathrm{O}_{3}$, between the University of Houston and downtown Houston. Details of the LP-DOAS instrument can be found in Alicke et al. (2002), Stutz et al. (2010a,b) and Platt and Stutz (2008). The absorption spectra were used to retrieve the path-average concentrations of the trace gases. The retrieved concentrations are horizontally averaged between the Moody Tower and downtown Houston and vertically averaged between the LP-DOAS height intervals (lower: $20-70 \mathrm{~m}$, middle: $70-130 \mathrm{~m}$ and upper: $130-300 \mathrm{~m}$ ) and are representative concentrations for the boxes shown in Fig. 2. The concentration in the upper box is determined by subtracting the concentration of the middle light path scaled by the geometric overlap from the upper light path. Therefore, the concentration in the upper box is weighted more towards downtown. The uncertainties of the $\mathrm{NO}_{2}, \mathrm{O}_{3}$, and HONO absorption cross sections are $\pm 5 \%, \pm 3 \%$, and $\pm 5 \%$, respectively (Voigt et al., 2001; Stutz et al., 2002; Voigt et al., 2002). The systematic error of the DOAS spectrometer was determined to be $<3 \%$ (Stutz and Platt, 1996). The observed mixing ratio ranges and detection limits are shown in Table 1. Information on supplemental measurements during TRAMP can be found in Lefer and Rappenglück (2010).

\section{Observations}

During the measurement period from 15 August to 20 September in 2006 during TRAMP, the best data on all three light paths were obtained during the first two weeks of September (1-14 September). Therefore, the discussion below is focused on this period (Fig. 3). All three trace gases established vertical gradients at night which disappeared in the morning when the boundary layer became well-mixed.

\subsection{Meteorology}

In-situ measurements of meteorological data, such as wind, temperature and relative humidity were recorded at the top of Moody Tower during the experiment. Wind speed and direction, temperature and relative humidity data are plotted in 


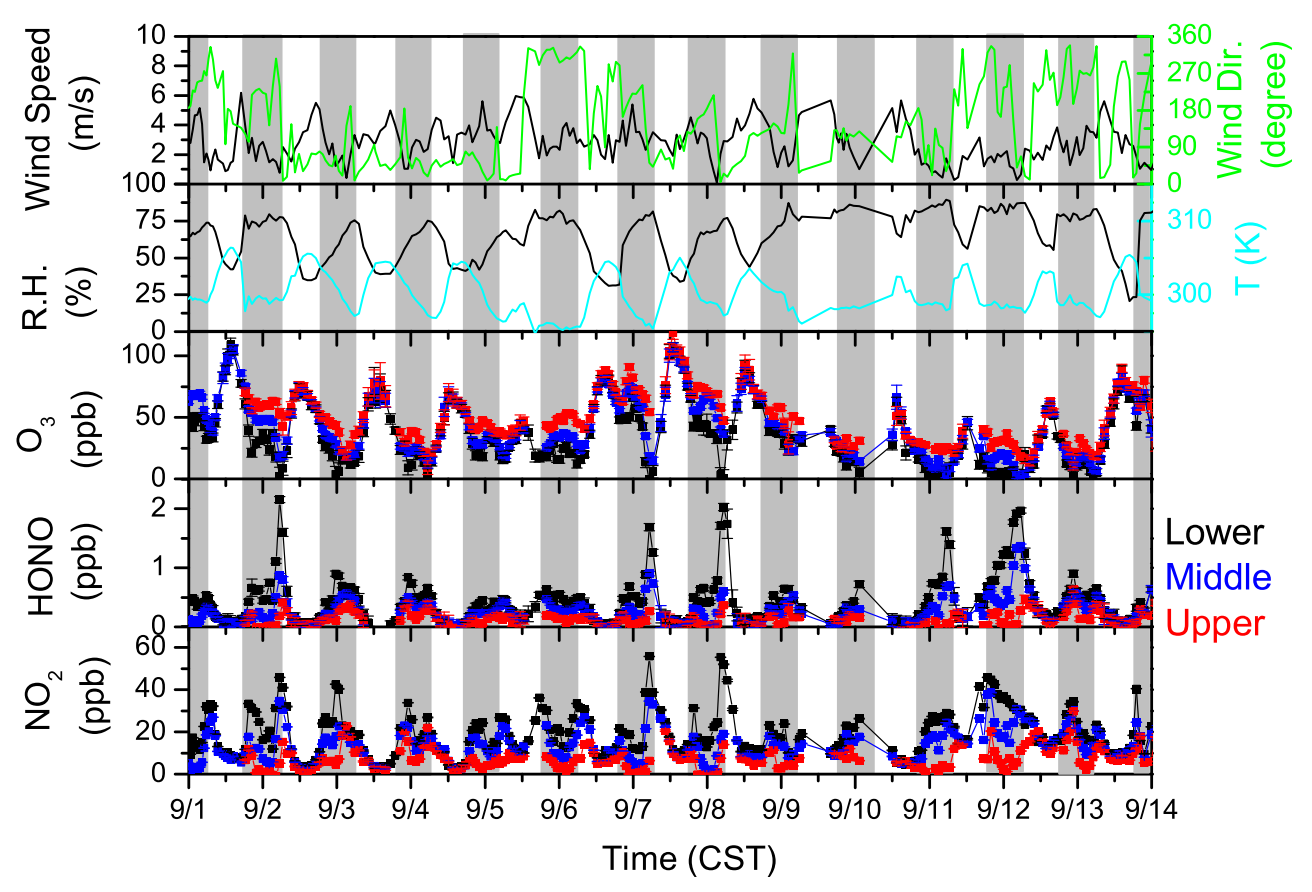

Fig. 3. Overview of LP-DOAS observations of $\mathrm{NO}_{2}$, $\mathrm{HONO}$ and $\mathrm{O}_{3}$ mixing ratios (lower: $20-70 \mathrm{~m}$, middle: $70-130 \mathrm{~m}$ and upper: 130$300 \mathrm{~m}$ ) from 1-14 September 2006 during TRAMP in Houston, TX. Measurements of temperature, relative humidity and wind speed and direction at $70 \mathrm{~m}$ are also shown. Nighttime data are shaded in grey to differentiate from daytime observations.

Fig. 3. During the measurement period from 1 to 14 September 2006, the prevailing winds were mostly northeasterly, with an average wind speed of $\sim 3 \mathrm{~m} / \mathrm{s}$. At night, winds tended to be weaker than during the day, with an average of $2.5 \mathrm{~m} / \mathrm{s}$. However, wind directions were mostly northeasterly or southeasterly. Relative humidity during these two weeks ranged from $20 \%$ to $90 \%$, with, in general, larger relative humidity at night. Details of the meteorology conditions during TRAMP are discussed in Lefer et al. (2010).

\section{$3.2 \quad \mathrm{NO}_{2}$ and $\mathrm{O}_{3}$}

$\mathrm{NO}_{2}$ developed negative gradients during the night, with larger mixing ratios near the ground and smaller aloft, while positive gradients of $\mathrm{O}_{3}$ were typically observed. This was due to the suppression of vertical mixing at night and $\mathrm{NO}$ emissions from traffic at the surface that converts $\mathrm{O}_{3}$ to $\mathrm{NO}_{2}$ as shown in Reaction (R4). These gradient measurements are consistent with previous field observations (Wang et al., 2006; Stutz et al., 2004b).

$\mathrm{NO}+\mathrm{O}_{3} \longrightarrow \mathrm{NO}_{2}+\mathrm{O}_{2}$

During stable and polluted nights $(1-2,2-3,6-7,7-8$ and 11-12 September), $\mathrm{NO}_{2}$ mixing ratios at the lower height interval reached above $40 \mathrm{ppb}$ while $\mathrm{NO}_{2}$ mixing ratios in the upper height interval were $\sim 1 \mathrm{ppb}$ or less. Differences of $\mathrm{NO}_{2}$ mixing ratios between lower and upper height intervals reached up to $50 \mathrm{ppb}$, as observed on 7 September at 04:30 CST.
$\mathrm{O}_{3}$ mixing ratios in the lower height interval decreased throughout the night and were often below $20 \mathrm{ppb} . \mathrm{O}_{3}$ mixing ratios decreased to below a few ppb during several nights (1-2, 2-3, 6-7, 7-8, 10-11, and 11-12 September). During these nights, $\mathrm{O}_{3}$ mixing ratios in the upper height interval remained almost constant throughout the night. Differences of $\mathrm{O}_{3}$ mixing ratios between lower and upper light paths exceeded $50 \mathrm{ppb}$ on 2 and 7 September.

\subsection{HONO}

During the night, HONO generally followed the trend of $\mathrm{NO}_{2}$ in all three height intervals. Negative vertical gradients were observed during the night, with larger concentrations near the ground and smaller aloft, similar to previous observations (Wang et al., 2006; Stutz et al., 2002; Kleffmann et al., 2003). Maximum nighttime HONO mixing ratios of $2 \mathrm{ppb}$ and above were observed in the lower height interval on 1-2, 7-8 and 11-12 September. Differences of HONO mixing ratios between the lower and upper height intervals reached up to $1.5 \mathrm{ppb}$ during the nights of $1-2,6-7,7-8,10$ 11 and 11-12 September.

\subsubsection{Selected polluted nights (1-2, 7-8 and 11-12 September)}

Three periods (1-2, 7-8 and 11-12 September) (Figs. 4a, 5a, 6a) were selected for a more detailed analysis. These nights were selected based on the distinct $\mathrm{NO}_{2}$ and $\mathrm{O}_{3}$ vertical 

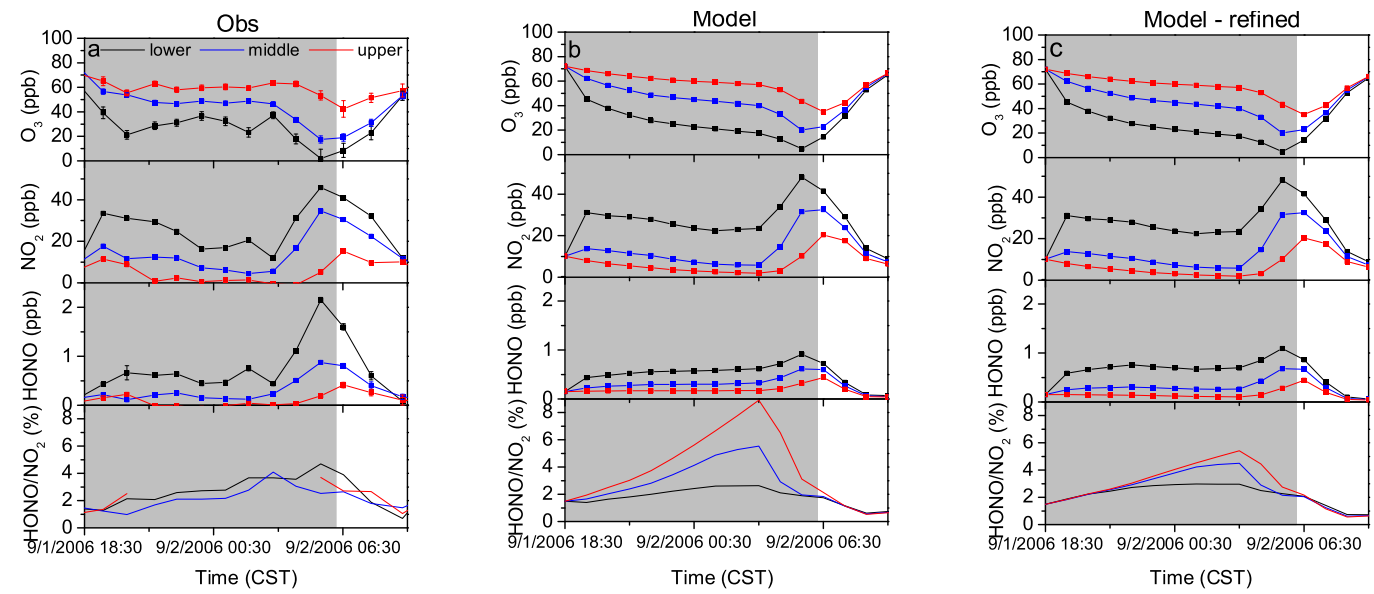

Fig. 4. Comparison of $\mathrm{HONO}, \mathrm{NO}_{2}, \mathrm{O}_{3}$ mixing ratios and $\mathrm{HONO}$ to $\mathrm{NO}_{2}$ ratios between observations (left) and model results (middle and right) on 1-2 September 2006. (Mixing ratios at lower, middle and upper altitudes are plotted in black, blue and red respectively.) See the Supplement for expanded version of figure.
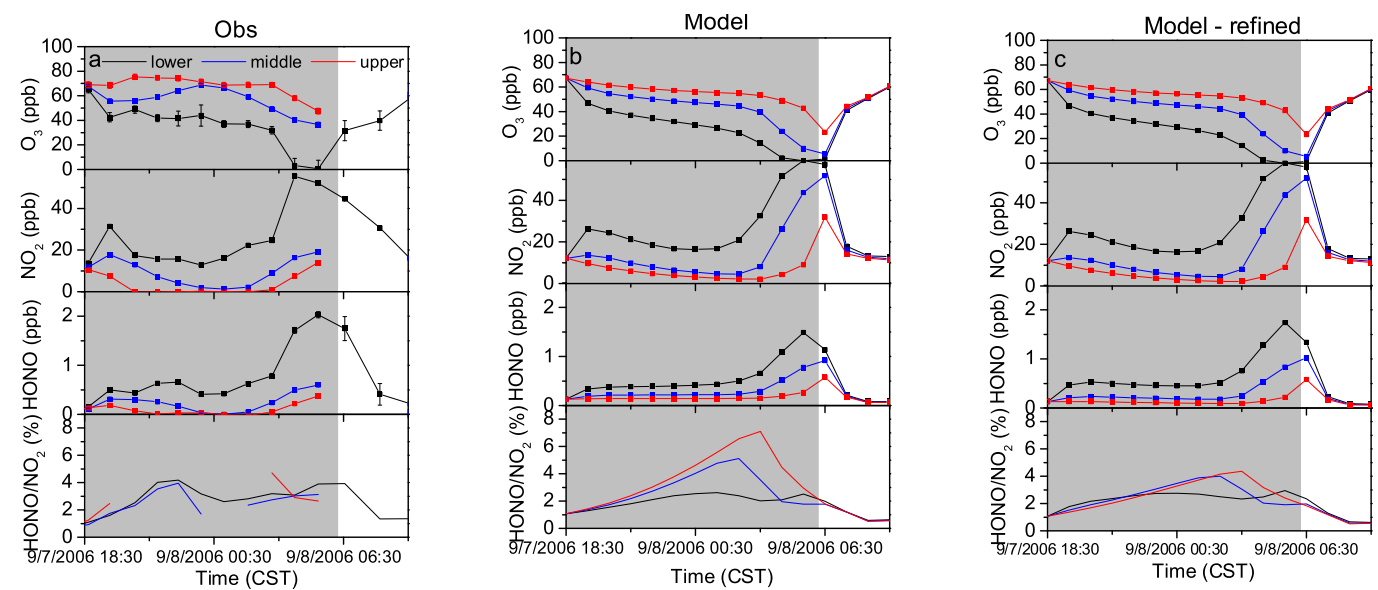

Fig. 5. Comparison of $\mathrm{HONO}, \mathrm{NO}_{2}, \mathrm{O}_{3}$ mixing ratios and $\mathrm{HONO}$ to $\mathrm{NO}_{2}$ ratios between observations (left) and model results (middle and right) on 7-8 September 2006. (Mixing ratios at lower, middle and upper altitudes are plotted in black, blue and red respectively.) See the Supplement for expanded version of figure.

gradients, which indicate a stable atmosphere. HONO profiles were not considered in the selection of the nights. However, our observations during TRAMP show that nights with stable boundary layers result in strong HONO gradients. 1-2 and 7-8 September had similar nocturnal variations of $\mathrm{NO}_{2}$, $\mathrm{HONO}$ and $\mathrm{O}_{3}$ with other nights. Vertical gradients of all three trace gases started to develop after sunset and became strongest towards the end of the night. Strong positive gradients of $\mathrm{O}_{3}$ and negative gradients of $\mathrm{NO}_{2}$ were observed. $\mathrm{O}_{3}$ at lower levels became depleted at the end of both nights, while the upper light path showed almost constant mixing ratios of about $60 \mathrm{ppb}$ and $70 \mathrm{ppb}$ throughout the nights. Based on the vertical trace gas profiles, temperature profiles (Day et al., 2010) and the results from our previous $\mathrm{NO}_{3}$ lifetime analysis (Stutz et al., 2010b) we believe that the upper height interval was partially in the residual layer during both nights.
The residual layer began at $200 \mathrm{~m}$ and $160 \mathrm{~m}$ respectively for 1-2 and 7-8 September, assuming the residual layer was located right above the nocturnal ground inversion (Day et al., 2010). HONO mixing ratios at all three levels, lower, middle and upper, were positively correlated with $\mathrm{NO}_{2}$. The correlation coefficients $R^{2}$ were 0.80 and 0.90 , respectively, for $1-2$ and 7-8 September. Nighttime HONO concentrations were largest about an hour before sunrise and reached $2.15 \mathrm{ppb}$ on 2 September and $2 \mathrm{ppb}$ on 8 September in the lower height interval. During both nights, HONO mixing ratios in the upper height interval remained below $0.1 \mathrm{ppb}$. Differences in HONO mixing ratios between the lower and upper light paths reached $2.0 \mathrm{ppb}$ and $1.7 \mathrm{ppb}$ during the night of 1-2 and 7-8 September, respectively. The main difference between these two nights was that $\mathrm{HONO}$ and $\mathrm{NO}_{2}$ mixing ratios in the lower height interval reached their maximum at the same 

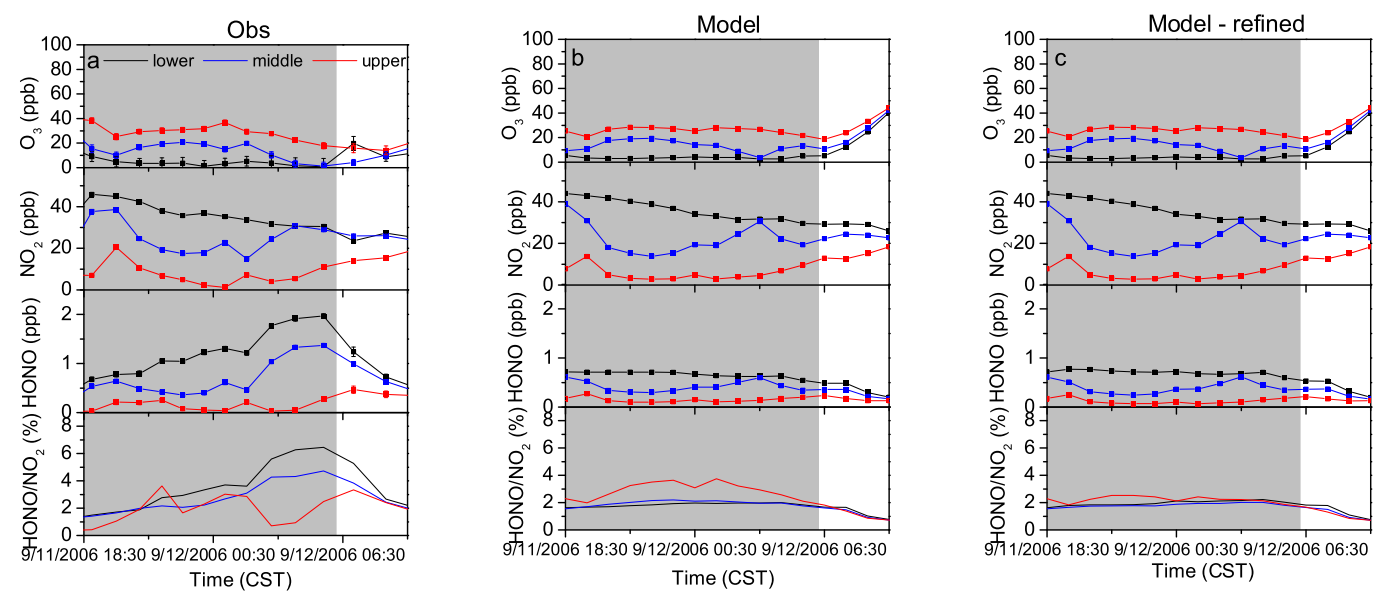

Fig. 6. Comparison of $\mathrm{HONO}, \mathrm{NO}_{2}, \mathrm{O}_{3}$ mixing ratios and $\mathrm{HONO} / \mathrm{NO}_{2}$ between observations (left) and model results (middle and right) on 11-12 September 2006. (Mixing ratios at lower, middle and upper altitudes are plotted in black, blue and red respectively.) See the Supplement for expanded version of figure.

time during the night of 1-2 September, but $\mathrm{NO}_{2}$ peaked an hour earlier than HONO during the night of 7-8 September.

The night of 11-12 September showed a very different picture. $\mathrm{HONO}$ and $\mathrm{NO}_{2}$ mixing ratios at the lower light path did not follow each other closely as was typically observed during other nights. Instead, $\mathrm{NO}_{2}$ in the lower height interval decreased throughout the night, while HONO accumulated. However, $\mathrm{HONO}$ in the middle and upper interval showed a slightly positive correlation with $\mathrm{NO}_{2}$, with an $R^{2}$ of 0.59 . Differences in HONO mixing ratios between the lower and upper light paths reached $1.9 \mathrm{ppb}$. In addition, vertical gradients of $\mathrm{O}_{3}, \mathrm{HONO}$ and $\mathrm{NO}_{2}$ were observed already at the beginning of this night, while they were well-mixed at the beginning of the nights of 1-2 and 7-8 September and. This indicated the atmosphere was already stable before sunset.

Following the idea that the $\mathrm{HONO}$ to $\mathrm{NO}_{2}$ ratios allow further analysis of $\mathrm{NO}_{2}$ to $\mathrm{HONO}$ conversion (Stutz et al., 2004a) we also calculated this ratio (Fig. 4a, 5a, 6a). $\mathrm{HONO} / \mathrm{NO}_{2}$ was about $1-2 \%$ at the beginning of all three nights. $\mathrm{HONO} / \mathrm{NO}_{2}$ tended to be slightly larger at lower levels than aloft. There were no significant vertical gradients of the ratio except on 11-12 September, during the last few hours of the night. At the lower level, the ratios increased throughout the night and reached a maximum of $4 \%$ and $6 \%$, respectively, on 2 September and 12 September at the end of the night when HONO reached a maximum. On 78 September, $\mathrm{HONO} / \mathrm{NO}_{2}$ increased to $4 \%$ before midnight then remained above $3 \%$ throughout the night. Compared with results from Stutz et al. (2004a), the $\mathrm{HONO} / \mathrm{NO}_{2}$ during TRAMP seems to be lower. While $\mathrm{HONO} / \mathrm{NO}_{2}$ of up to $9 \%$ were observed in various field experiments as reported in Stutz et al. (2004a), a maximum ratio of $7 \%$ was measured during TRAMP. It should be noted here that the values reported by Stutz et al. (2004a) were corrected for direct emis- sion of HONO and are thus expected to be larger. For a better comparison with the model we will use directly observed and modeled $\mathrm{HONO} / \mathrm{NO}_{2}$, without any further correction.

\section{Model description}

To further understand the HONO field measurements taken during TRAMP 2006, we used a 1-D Radical Chemistry and Transport model (RCAT8.2). RCAT8.2 includes the gas-phase Regional Atmospheric Chemistry Mechanism (RACM) and 84 reactive species and 244 gas phase chemical reactions (Stockwell et al., 1997). RCAT8.2 considers temporally varying anthropogenic emissions, predominately from traffic between $0.1 \mathrm{~m}$ and $1 \mathrm{~m}$ altitude, as well as biogenic emissions at the ground and between $1 \mathrm{~m}$ and $10 \mathrm{~m}$ altitude. Emission ratios used in the model are based on (Kurtenbach et al., 2001, 2002). Surface uptake resulting in dry deposition and chemistry on aerosol are included as well. Chemistry in the liquid phase is currently not considered in the model. Details of the model are described in Geyer and Stutz (2004a) and Wong and Stutz (2010).

\subsection{Model setup}

The model subdivides the lowest $2 \mathrm{~km}$ into 26 boxes (center of boxes at (m): $5 \times 10^{-5}, 5.5 \times 10^{-4}, 5.5 \times 10^{-3}, 5.5 \times 10^{-2}$, $0.55,2,4.5,8,15,27.5,42.5,60,80,100,120,140,162.5$, $187.5,250,400,625,875,1125,1375,1625,1975,2500)$. Box heights decrease logarithmically below $1 \mathrm{~m}$ to take into account the inefficient vertical transport near the ground. An additional box from $2 \mathrm{~km}$ to $3 \mathrm{~km}$ is the upper boundary of the model. Vertical exchange of trace species between adjacent boxes occurs through turbulent diffusion as chemical reactions take place simultaneously at all altitudes. 


\subsection{Parameterization of HONO chemistry}

In RCAT8.2 HONO is directly emitted from cars with an emission ratio $\mathrm{HONO} / \mathrm{NO}_{\mathrm{x}}=0.008$ between $0.1-1 \mathrm{~m}$ altitude based on the tunnel measurement from Kurtenbach et al. (2001). Chemical HONO reactions currently considered in the model include HONO photolysis (Reaction R1), the HONO reaction with $\mathrm{OH}$ and the formation of HONO from $\mathrm{NO}$ and $\mathrm{OH}$ (Reaction $\mathrm{R} 2$ ).

$\mathrm{HONO}$ is formed from conversion from $\mathrm{NO}_{2}$ on aerosol and ground surfaces, with a yield of $50 \%$ following the stoichiometry of Reaction (R3) and an $\mathrm{NO}_{2}$ reactive uptake coefficient of $10^{-5}$ (Trick, 2004). Deposition rates of HONO and $\mathrm{NO}_{2}$ are calculated by the number of molecules in the lowest box colliding with the ground and the uptake coefficient. The uptake rate of $\mathrm{HONO}$ and $\mathrm{NO}_{2}$ on aerosols is determined from the aerosol surface area density and the uptake coefficients according to the mass-transfer equation given by (Fuchs and Sutugin, 1971) assuming an average particle diameter of $150 \mathrm{~nm}$.

HONO is taken up on aerosol and ground surfaces with a reactive uptake coefficient of $10^{-4}$ (Trick, 2004). The ground is assumed to be flat in the model and no buildings or trees are considered. The aerosol vertical profile is assumed to be uniform. Vertical transport of HONO, i.e. vertical HONO flux $j_{\mathrm{HONO}}$ is calculated based on a flux-gradient relationship and eddy diffusivity (Eq. 1) (Geyer and Stutz, 2004a). Eddy diffusivity is calculated by the Monin-Obukhov theory with the Von Kármán constant $\kappa$, the friction velocity $u^{*}$ and the stability correction factor $\Phi$ which is a function of altitude and stability through the Obukhov length $L$ (Businger et al., 1971).

$j_{\mathrm{HONO}}(z, t)=-K(z, t) \cdot \frac{\partial \mathrm{HONO}(z, t)}{\partial z}$,

where $K(z, t)=\frac{\kappa \cdot u^{*}(t) \cdot z}{\Phi\left(\frac{z}{L}, t\right)}$

\subsection{Model initialization}

The model was initialized with a well-mixed boundary layer, using observed concentrations after sunset at 18:30 CST on 1 September and 7 September (Table 2). For the period of 1112 September, the model was initialized with the observed vertical profiles of $\mathrm{NO}_{2}$, $\mathrm{HONO}$ and $\mathrm{O}_{3}$ and a stable boundary layer (Table 2). Since no observations were available below $20 \mathrm{~m}$, the lowest 9 boxes, which are located below $20 \mathrm{~m}$ in the model, were initialized by extrapolating the LP-DOAS observations in in lowest height interval. Because other trace gases such as $\mathrm{SO}_{2}$ and $\mathrm{HCHO}$ did not show any vertical gradients at this time, all trace gases except $\mathrm{NO}_{2}, \mathrm{HONO}$ and $\mathrm{O}_{3}$ were initialized with a constant vertical profile for this night. Observed volatile organic compounds (VOC) concentrations at $70 \mathrm{~m}$, assumed to be constant at all heights, were used in all three model runs (Leuchner and Rappenglück, 2010) (Table 2).
Table 2. Initial concentrations in ppb for model simulations.

\begin{tabular}{llll}
\hline & 1 September & 7 September & 11 September \\
\hline $\mathrm{O}_{3}$ & 72 & 67 & Low: 9; Mid: 15; Up: 38 \\
$\mathrm{NO}_{2}$ & 10 & 12 & Low: 40; Mid: 37 Up: 7 \\
$\mathrm{HONO}$ & 0.15 & 0.13 & Low: 0.68; Mid: 0.53 Up: 0.03 \\
$\mathrm{SO}_{2}$ & 5 & 3 & 3 \\
$\mathrm{CO}$ & 138 & 138 & 138 \\
$\mathrm{CH}_{4}$ & 1600 & 1600 & 1600 \\
Alkanes & 14.95 & 20.35 & 15.72 \\
Alkenes & 1.92 & 3.09 & 5.54 \\
Biogenics & 1.3 & 0.75 & 0.85 \\
Aromatics & 3.49 & 2.56 & 24.67 \\
Carbonlys & 8.52 & 8.62 & 7.55 \\
\hline
\end{tabular}

As previously described in Geyer and Stutz (2004a) nocturnal vertical profiles of most trace gases, and in particular $\mathrm{O}_{3}$ and $\mathrm{NO}_{\mathrm{x}}$, depend strongly on two factors: vertical stability and $\mathrm{NO}_{\mathrm{x}}$ emission rates. Both parameters are not known well enough for the TRAMP data to allow an accurate modeling of nocturnal chemistry. To ensure that we describe these two factors correctly before we attempt to simulate HONO profiles we adjusted $\mathrm{NO}_{\mathrm{x}}$ emission rates and vertical mixing at each hour to make the modeled temporal and vertical profiles of $\mathrm{NO}_{2}$ and $\mathrm{O}_{3}$ fit the measurement. Vertical mixing was adjusted indirectly by varying the Monin-Obukhov length, which was used to calculate the eddy diffusivity. It should be noted here that the model was not constrained by any observed trace gas concentrations after initialization. HONO profiles were then calculated based on the adjusted emissions and stability parameters using the chemistry described above. No attempt to adjust the model to the HONO observations was made.

\subsection{Applicability of 1-D model}

One of the obvious challenges in our approach is the use of a 1-D model that may have difficulties in situations where advection plays a role. Emissions from point-sources pose another obstacle for the 1-D model. However, unlike many previous comparisons between observations and model results our 1-D model was used to understand path-averaged LP-DOAS data. These observations were horizontally integrated over $4-5 \mathrm{~km}$ and vertically integrated over altitudes of $20-70 \mathrm{~m}, 70-130 \mathrm{~m}$ and $130-300 \mathrm{~m}$. Therefore, any local effects such as freeways and small scale trace gas transport will be averaged and play a much smaller role than in comparisons with in-situ data.

The DOAS measurements are also representative for much larger areas. In Houston the light paths spanned approximately from downtown to the southern edge of the inner ring of Houston, bounded by Freeway 610 (Fig. 2). Since the Houston inner ring consists of urban and suburban areas with similar characteristics, the LP-DOAS observations should also be representative for the rest of the Houston inner ring. 


\subsubsection{Lateral transport}

To investigate how trace gas advection could impact our modeling studies, we compared the vertical mixing timescale in the model with the observed horizontal transport timescales. The vertical mixing timescale in the model is calculated as $\tau_{z}(z, t)=\frac{z}{\kappa \cdot u^{*}(t)}$, where $z$ is the altitude, $\kappa$ is the Von Kármán constant and $u^{*}$ is the friction velocity. The horizontal timescale was determined using the measured wind speed and assuming that our LP-DOAS measurements are representative for the Houston inner ring with $\sim 20 \mathrm{~km}$ diameter. The 1-D model can be used if the vertical mixing timescale is much less than the horizontal timescale, i.e. $\tau_{z} \ll \tau_{\mathrm{x}}$. In this case concentration changes due to advection are less than those caused by vertical transport and trace gas distribution in the lower atmosphere is governed by vertical transport rather than lateral transport. Typical vertical transport timescale from the ground to $100 \mathrm{~m}$ in the NBL is about $10^{3} \mathrm{~s}$ and the horizontal transport timescale is about $10^{4} \mathrm{~s}$ for the area inside the Houston inner ring, for which our LP-DOAS observations are representative. The comparison between the vertical and horizontal timescales showed that our 1-D model can be used to simulate the lower and the middle height intervals. However, care has to be taken in the interpretation of the model calculations of the upper interval $(130-300 \mathrm{~m})$ as advection may potentially play a role. This is in agreement with a previous study (Stutz et al., 2010b) that concluded that the upper height interval was frequently in the residual layer in Houston.

\subsubsection{Point emission}

Another challenge in the use of the 1-D model is upwind point emissions, for example from the petrochemical complex in the Houston ship channel area east of our measurement site. During easterly winds these emissions, which would be inhomogeneously distributed in the atmosphere, could reach our light paths. However, in-situ wind speed and direction measured at $70 \mathrm{~m}$ altitude at Moody Tower and radiosonde profiles (Day et al., 2010) showed that wind directions were not easterly during the three modeling periods and thus there was no significant influence of the ship channel emissions on our data. The only exception is 7-8 September between 03:30 to 04:00 CST in the lower and middle height intervals when an increase of about $10 \mathrm{ppb}$ of $\mathrm{NO}_{2}$ and $0.5 \mathrm{ppb}$ of HONO in the lower interval, and a slight increase of $\mathrm{NO}_{2}$ and $\mathrm{HONO}$ in the middle interval occurred. For our study we will thus treat the Houston inner ring as a metropolitan area where traffic is the dominant source of $\mathrm{NO}_{\mathrm{x}}$ and $\mathrm{HONO}$ emission (Fig. 2).

\subsection{Sensitivity to emission and vertical mixing}

Sensitivity studies based on the model run of 1-2 September were performed to investigate the dependence of $\mathrm{NO}_{2}$ and $\mathrm{O}_{3}$ mixing ratios on $\mathrm{NO}_{\mathrm{x}}$ emission and vertical mixing (Fig. 7). $\mathrm{NO}_{\mathrm{x}}$ emission, adjusted to yield agreement with the observations, showed the evening rush hours in the first few hours of the model runs, followed by low emissions throughout the night until the onset of the morning rush hours. Similar emission patterns were found in the modeling periods of 7-8 and 11-12 September. Variation of eddy diffusivity, also adjusted for best agreement between modeled $\mathrm{NO}_{2}$ and $\mathrm{O}_{3}$, showed that the boundary layer was weakly stable during the first two hours and stable throughout the rest of the night. Similar eddy diffusivities were used during the night of 78 September. 11-12 September had a less stable boundary layer since observations showed some mixing between the lower and middle height intervals.

$\mathrm{NO}_{2}$ mixing ratios in the lower height intervals were very sensitive to changes in $\mathrm{NO}_{\mathrm{x}}$ emissions. A change of $20 \%$ in $\mathrm{NO}_{\mathrm{x}}$ emissions in the model run will lead to a significant change in modeled $\mathrm{NO}_{2}$ mixing ratios. Sensitivity of $\mathrm{NO}_{2}$ to $\mathrm{NO}_{\mathrm{x}}$ emissions decreases with altitude. As shown in Fig. 7, an uncertainty of $+/-20 \%$ in the $\mathrm{NO}_{\mathrm{x}}$ emission rates seems to capture the disagreement between the best modeled $\mathrm{NO}_{2}$ mixing ratio and the observations on both light paths throughout the night. $\mathrm{NO}_{2}$ concentrations did not seem to be very sensitive to variations in eddy diffusivity. However, eddy diffusivity values were small during the night. Thus changes of eddy diffusivity adopted in the sensitivity runs did not make a significant change in the stability or vertical mixing of the boundary layer. Sensitivity of $\mathrm{NO}_{2}$ to eddy diffusivity also decreases with altitude.

The sensitivity runs also show that our method of adjusting $\mathrm{NO}_{\mathrm{x}}$ emissions and vertical mixing seems to yield reasonable and fairly accurate results. We thus conclude that the adjusted $\mathrm{NO}_{\mathrm{x}}$ emissions and vertical mixing parameters provide accurate input parameters for our model runs to study HONO chemistry.

\section{Modeling results}

Model results for 1-2, 7-8 and 11-12 September are shown in Figs. 4b, 5b, 6b. For a better comparison with the observations we integrated the mixing ratios from the model over the three observational height intervals, i.e. lower $(20-70 \mathrm{~m})$, middle (70-130 m) and upper (130-300 m).

\section{$5.1 \quad \mathrm{NO}_{2}$ and $\mathrm{O}_{3}$}

The modeled $\mathrm{NO}_{2}$ and $\mathrm{O}_{3}$ mixing ratios for all three nights (1-2, 7-8 and 11-12 September) agree well with the observations, except for $\mathrm{NO}_{2}$ in the upper height interval which tends to be larger than the measurements on 1-2 and 78 September. Because the upper height interval was most likely in the residual layer during these nights, the weak mixing into the residual layer and/or the possible air mass exchange above $130 \mathrm{~m}$ was not simulated accurately in the 

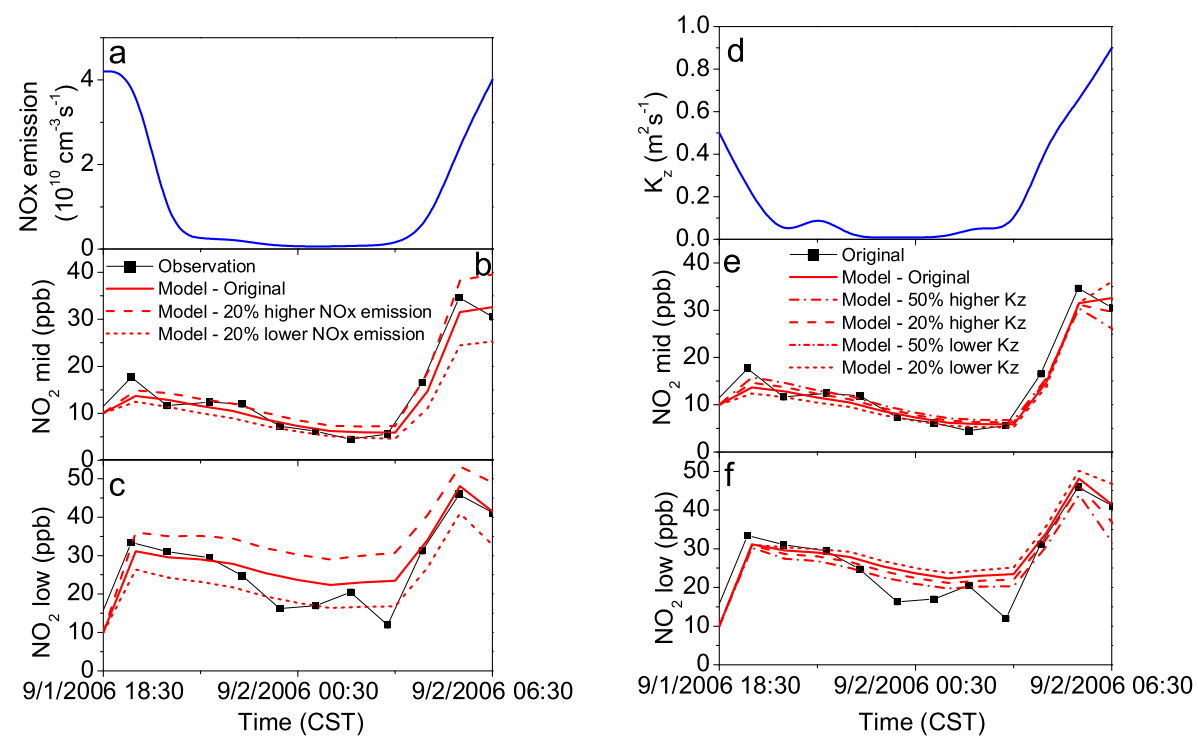

Fig. 7. Sensivity of $\mathrm{NO}_{2}$ mixing ratios in the lower and middle light paths intervals to change in $\mathrm{NO}_{\mathrm{x}}$ emission and eddy diffusivity. $\mathrm{NO}_{\mathrm{x}}$ emission and eddy diffusivity at $10 \mathrm{~m}$ are plotted as well.

model. On 11-12 September, mixing of $\mathrm{NO}_{2}$ at the lower and middle height intervals occurred in the second half of the night. This was simulated until the two were well-mixed, but the modeled $\mathrm{NO}_{2}$ again developed gradients while the observed $\mathrm{NO}_{2}$ between the lower and middle light path intervals remained well-mixed.

\subsection{HONO}

The modeled HONO mixing ratios and profiles showed good agreement with the observations for 1-2 and 7-8 September, except for the last few hours of the night when HONO was under-predicted by the model. HONO mixing ratios in the upper height interval were greater in the model than the observations, as the upper height interval was often located in the residual layer. The elevated HONO at this altitude was probably due to an overestimate of vertical mixing into the residual layer by the model and/or transport processes in the residual layer which are not represented well in the model.

Comparison of $\mathrm{HONO} / \mathrm{NO}_{2}$ from the model with the observations allows further analysis of the HONO formation processes and their altitude dependence. Our model calculation showed a surprising increase of $\mathrm{HONO} / \mathrm{NO}_{2}$ with altitude on 1-2 and 7-8 September, which was not reflected in the observations. This suggested that there was either too little $\mathrm{NO}_{2}$ and/or too much $\mathrm{HONO}$ in the middle and upper altitude intervals in the model. Sensitivity studies revealed that increasing $\mathrm{NO}_{2}$ in the model leads to $\mathrm{NO}_{3}$ and $\mathrm{N}_{2} \mathrm{O}_{5}$ mixing ratios which were considerably larger than the observations (Stutz et al., 2010b). We thus concluded that the increase of $\mathrm{HONO} / \mathrm{NO}_{2}$ aloft was due to excess HONO instead of the lack of $\mathrm{NO}_{2}$. Attempts to decrease the $\mathrm{HONO} / \mathrm{NO}_{2}$ at middle and upper altitudes by adjusting the uptake coefficients of $\mathrm{NO}_{2}$ and/or the conversion factor of $\mathrm{NO}_{2}$ were not successful. Further analysis of HONO chemistry showed that the elevated $\mathrm{HONO} / \mathrm{NO}_{2}$ was most likely due to an underestimate of the loss of HONO on the aerosol. Modeled $\mathrm{HONO} / \mathrm{NO}_{2}$ in the lower height interval for the three periods was slightly lower than the observations, indicating that HONO was formed at the ground more efficiently than implemented in our original model. Sensitivity studies showed that the underestimated $\mathrm{HONO} / \mathrm{NO}_{2}$ at lower altitude interval was due to the excess loss of HONO by deposition on the ground.

To consider the excess loss of $\mathrm{HONO}$ at the ground and the inadequate loss of HONO on aerosol in the model, refined model runs were carried out in which the HONO uptake coefficient at the ground was decreased by a factor of five to $2 \times 10^{-5}$, while the HONO uptake on the aerosol was increased ten times to $10^{-3}$. In our original model runs HONO uptake coefficients on aerosol and ground were $10^{-4}$, based on measurements on asphalt by Trick (2004). In reality, the uptake coefficients are likely to be different on aerosol and ground. HONO uptake coefficients on the order of $10^{-4}$ to $10^{-2}$ were reported by several studies (Yu et al., 2009). HONO uptake coefficients on sulfate particles on the order of $10^{-3}$ were reported by Harrison and Collins (1998). The HONO uptake coefficient used in our refined model runs thus seems to be within the range of published values.

The refined model results (Figs. 4c, 5c, 6c) showed an increase of HONO mixing ratios at lower altitudes in all three runs compared to the original modeled results, leading to a better agreement between model and observations. There was no change in the modeled $\mathrm{NO}_{2}$ and $\mathrm{O}_{3}$ mixing ratios 
in the refined model runs. On 1-2 September, the modeled $\mathrm{HONO} / \mathrm{NO}_{2}$ in the lower and middle height intervals agreed very well with the observations until the last few hours of the night when the observed HONO mixing ratios increased and peaked. At 05:30 CST, the observed $\mathrm{HONO} / \mathrm{NO}_{2}$ reached $5 \%$ while the modeled ratio was only $2.5 \%$. This was most likely due to a process that leads to large $\mathrm{HONO} / \mathrm{NO}_{2}$ such as $\mathrm{HNO}_{3}$ conversion on fresh soot aerosol observed by Ziemba et al. (2010) during rush hour.

On 7-8 September, the modeled HONO in the lower height interval was slightly smaller in the middle of the night, but it showed a good agreement with the observations during the last few hours of the night. HONO reached a maximum of $1.7 \mathrm{ppb}$ in the model while the observed mixing ratio was 2 ppb. $\mathrm{HONO} / \mathrm{NO}_{2}$ in the lower height interval was better predicted on 7-8 Septenber in the refined model run. In both modeling periods, 1-2 and 7-8 September, the HONO mixing ratios at upper altitude intervals were larger than the observations as the upper light path was located in the residual layer which was not captured accurately by the model.

In general, the refined model improved the agreement between model and observations on 1-2 and 7-8 September. However, the model was not able to reproduce the opposite temporal behavior of $\mathrm{HONO}$ and $\mathrm{NO}_{2}$ in the lower height interval during the night of 11-12 September. The modeled HONO mixing ratios in the lower height interval remained constant at about $0.7 \mathrm{ppb}$ and decreased slightly towards the end of the night while the observed HONO increased steadily throughout the night to $2 \mathrm{ppb}$ at the end of the night. In addition, the modeled $\mathrm{HONO} / \mathrm{NO}_{2}$ remained almost constant at around $2 \%$ throughout the night and did not predict the increase of $\mathrm{HONO} / \mathrm{NO}_{2}$ to $6 \%$, as observed. This night differed in its behavior considerably from the other two. 11-12 September was the only night throughout the two weeks of measurements (Fig. 3) with opposite temporal behavior of $\mathrm{HONO}$ and $\mathrm{NO}_{2}$. The decrease of $\mathrm{NO}_{2}$ at the lower light path throughout the night was due to the low $\mathrm{O}_{3}$ at the beginning of the night. As surface $\mathrm{NO}_{2}$ was predominately formed from the reaction of ozone with $\mathrm{NO}(\mathrm{R} 4)$, the $\mathrm{NO}_{2}$ surface source was small in this night. This interpretation is consistent with the very low $\mathrm{NO}_{3}$ mixing ratio observations (not shown). It is not clear what caused the increase of HONO with decreasing $\mathrm{NO}_{2}$ at lower altitude intervals. One possible explanation was the more efficient HONO formation at larger relatively humidity as reported by Stutz et al. (2004a), as this night was more humid than the other two. The average relatively humidity at $70 \mathrm{~m}$ was about $85 \%$ during this night and $70-75 \%$ during the other two periods. In addition, there was precipitation at the beginning of the night of 1112 September according to the National Climate Data Center (http://www.ncdc.noaa.gov/oa/climateresearch.html). We therefore conclude that precipitation processes wetting the ground and other surfaces during the night of 11-12 September lead to substantially different HONO chemistry, which is currently not implemented in the model. Because our model did not describe the HONO correctly, this night will not be further quantitatively analyzed below.

In the following we will focus on the refined model runs of 1-2 and 7-8 September, as the refined model runs describe the HONO chemistry better. To visualize the vertical mixing ratio profiles and their development throughout the night, the vertical profiles of $\mathrm{HONO}$ and $\mathrm{NO}_{2}$ mixing ratios at 19:30, 00:30 and 05:30 CST were extracted from the model simulations for the two modeling periods, 1-2 and 7-8 September (Fig. 8). HONO slowly accumulated in the lowest $200 \mathrm{~m}$ of the atmosphere, with pronounced vertical mixing ratio profiles. The actual vertical profiles should be slightly stronger because the modeled $\mathrm{NO}_{2}$ and $\mathrm{HONO}$ mixing ratios were overpredicted in the upper height interval. Vertical HONO gradients, i.e. comparing $20 \mathrm{~m}$ to $300 \mathrm{~m}$ altitude, increased throughout the night with changes occurring mainly below $100 \mathrm{~m}$, especially on 7-8 September. Most of the HONO was located in the lowest $200 \mathrm{~m}$ of the atmosphere. The modeled HONO mixing ratios below $20 \mathrm{~m}$, which were not observed by the LP-DOAS, showed that HONO near the ground (at $0.55 \mathrm{~m}$ ) increased from $1.8 \mathrm{ppb}$ at 19:30 CST to $2.4 \mathrm{ppb}$ at 00:30 CST and to $4.6 \mathrm{ppb}$ at 05:30 CST during the night of 7-8 September. This is significantly larger than the modeled and observed values of the lower light path of $0.45 \mathrm{ppb}$ at $19: 30,0.45 \mathrm{ppb}$ at $00: 30 \mathrm{CST}$ and $1.7 \mathrm{ppb}$ at $05: 30 \mathrm{CST}$. The vertical profiles of HONO indicated that HONO near the ground (at $0.55 \mathrm{~m}$ ) can be considerably larger than values from only $20-70 \mathrm{~m}$ above the surface. Consequently care has to be taken when extrapolating surface measurements of HONO to the entire boundary layer.

\section{Discussion}

Vertical profiles of HONO mixing ratios can give information on the nature of the surface responsible for the formation of HONO. Since HONO developed negative gradients throughout the night and its concentration increased near the ground throughout the night, one can interpret that the source of HONO is near or at the ground. It is however difficult to quantify the contributions of different HONO formation and loss processes and their altitude dependence based on vertical concentration profiles alone.

\subsection{HONO formation and loss rates profiles}

To further understand HONO chemistry and to investigate which processes are important for HONO in the nocturnal boundary layer, modeled HONO formation and loss rates were computed and the vertical profiles of these rates were extracted for the model period of 1-2 September at 19:30, 00:30 and 05:30 CST (Fig. 9). The rate of change of HONO depends on several factors as shown in Eq. (2). HONO is formed at the ground and potentially also on aerosol surfaces from $\mathrm{NO}_{2}$ conversion $\left(P_{\text {ground }}+P_{\text {aerosol }}\right)$, emitted from 

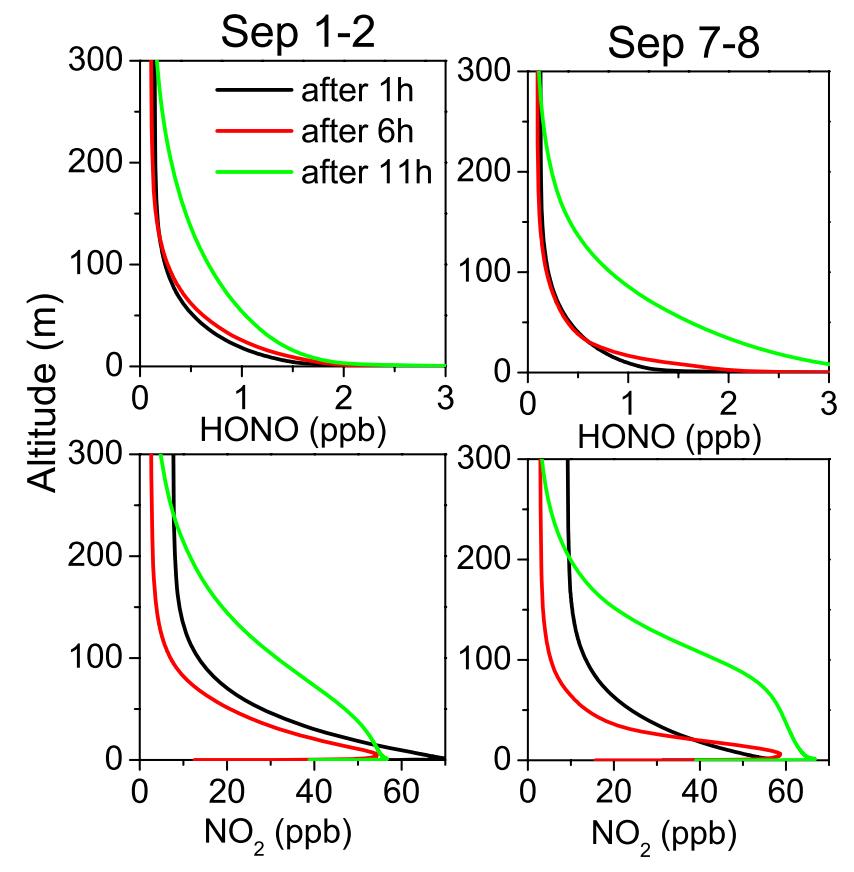

Fig. 8. Vertical profiles of modeled $\mathrm{HONO}$ and $\mathrm{NO}_{2}$ mixing ratios at 19:30, 00:30 and 05:30 CST of 1-2 September (left) and 7-8 September 2006 (right).

traffic $(E)$ and released through the reaction of NO and

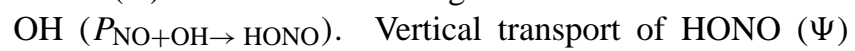
can be both a source and a sink. HONO in the nocturnal boundary layer can be lost through reaction with $\mathrm{OH}$ and deposition at the ground and uptake on aerosol surfaces ( $\left.L_{\text {ground }}+L_{\text {aerosol }}\right)$.

$$
\begin{aligned}
\frac{d \mathrm{HONO}}{d t} & =P_{\text {ground }}+P_{\text {aerosol }}+E+P_{\mathrm{NO}+\mathrm{OH}} \rightarrow \mathrm{HONO} \\
& +L_{\text {ground }}+L_{\text {aerosol }}+L_{\mathrm{HONO}+\mathrm{OH}}+\Psi
\end{aligned}
$$

The rate profiles (Fig. 9) show that HONO formation and loss processes were largest at or near the ground. The dominant formation pathway of $\mathrm{HONO}$ was through $\mathrm{NO}_{2}$ conversion at the ground, followed by direct HONO emission. HONO formation and uptake on aerosol surfaces occurred over the lowest $300 \mathrm{~m}$ with rates slowly increasing towards the ground, where $\mathrm{NO}_{2}$ and $\mathrm{HONO}$ mixing ratios are largest, assuming that the aerosol profile was uniform over the NBL. The formation of HONO on aerosol played a less important role. However, please note that aerosol surface profile in our model is oversimplified. The model predicted about $\sim 10^{5} \mathrm{~cm}^{-3}$ nocturnal $\mathrm{OH}$ from $\mathrm{NO}_{3}$ reactions with VOCs and ozonolysis of alkenes near the surface (see also Geyer and Stutz, 2004b). Production of HONO through reaction of $\mathrm{NO}$ and $\mathrm{OH}$ thus mainly occurred in the lower nocturnal boundary layer where NO mixing ratios were largest and decreased strongly with altitude. HONO formation by reaction of $\mathrm{NO}$ and $\mathrm{OH}$ was a minor production pathway of $\mathrm{HONO}$ in the NBL.

Among all the loss pathways, ground deposition of HONO was the largest. Chemical removal of $\mathrm{HONO}$ by $\mathrm{OH}$, which decreased exponentially with altitude, was negligible. HONO uptake on aerosol occurred over the lowest $300 \mathrm{~m}$ with rates increasing toward the ground where HONO concentrations were largest but, averaged over the NBL, this process was not as large as removal by ground deposition. Finally, HONO rate profiles showed that HONO vertical transport redistributed HONO over the boundary layer and in general transports HONO upward, leading to a loss of HONO near the ground and a gain of HONO at higher altitude. In all model runs, vertical transport was the dominant source of nocturnal HONO above $20 \mathrm{~m}$ altitude in average. Since the upper height interval was partially located in the residual layer where advection could play an important role, advection could potentially be a significant removal pathway of $\mathrm{HONO}$ in the residual layer.

\subsection{Integrated HONO production and loss}

Nocturnal HONO formation and removal rates change significantly throughout the nights of the two modeling periods due to the changes of meteorological condition and traffic patterns. In order to quantify the overall contribution of each HONO formation and loss process, the integrated HONO production and loss process in the lowest $300 \mathrm{~m}$ throughout the night were calculated for $1-2$ and 7-8 September (Table 3).

Vertically and nocturnally integrated HONO production ranged from $1.7 \times 10^{15} \mathrm{~cm}^{-2}$ to $1.8 \times 10^{15} \mathrm{~cm}^{-2}$ in the two modeling periods. Contribution to total HONO production was $65-74 \%$ by $\mathrm{NO}_{2}$ conversion at the ground, $3 \%$ by $\mathrm{NO}_{2}$ conversion on aerosol, $17-21 \%$ from traffic, and $6-21 \%$ from reaction of $\mathrm{NO}$ and $\mathrm{OH}$. Integrated $\mathrm{HONO}$ loss ranged from $1.3 \times 10^{15} \mathrm{~cm}^{-2}$ to $1.4 \times 10^{15} \mathrm{~cm}^{-2}$. Contribution of total HONO removal was $71-76 \%$ by ground deposition, $18 \%$ by aerosol uptake and $1 \%$ due to reaction of HONO with $\mathrm{OH}$. Vertical transport redistributed HONO over the NBL and even the residual layer. Vertical transport to altitudes above $300 \mathrm{~m}$ contributed to $5-10 \%$ of total HONO loss in the lowest $300 \mathrm{~m}$. Combining all the factors, the overall HONO net production was $2.7 \times 10^{14} \mathrm{~cm}^{-2}$ throughout the night of 1-2 September and $5.3 \times 10^{14} \mathrm{~cm}^{-2}$ for 7-8 September. Assuming that all the HONO formed at night photolyzed into $\mathrm{NO}$ and $\mathrm{OH}$, these numbers represent the amount of additional $\mathrm{OH}$ being contributed by $\mathrm{HONO}$ photolysis to the $\mathrm{OH}$ budget in the following day. However, because the HONO mixing ratios in the model simulations were smaller than the observations during the last few hours of the night, the actual HONO formation during these two nights should have been even greater. The inclusion of the upper height interval in our integration calculations leads to up to $20 \%$ uncertainty in HONO formation and loss on aerosol surfaces, 


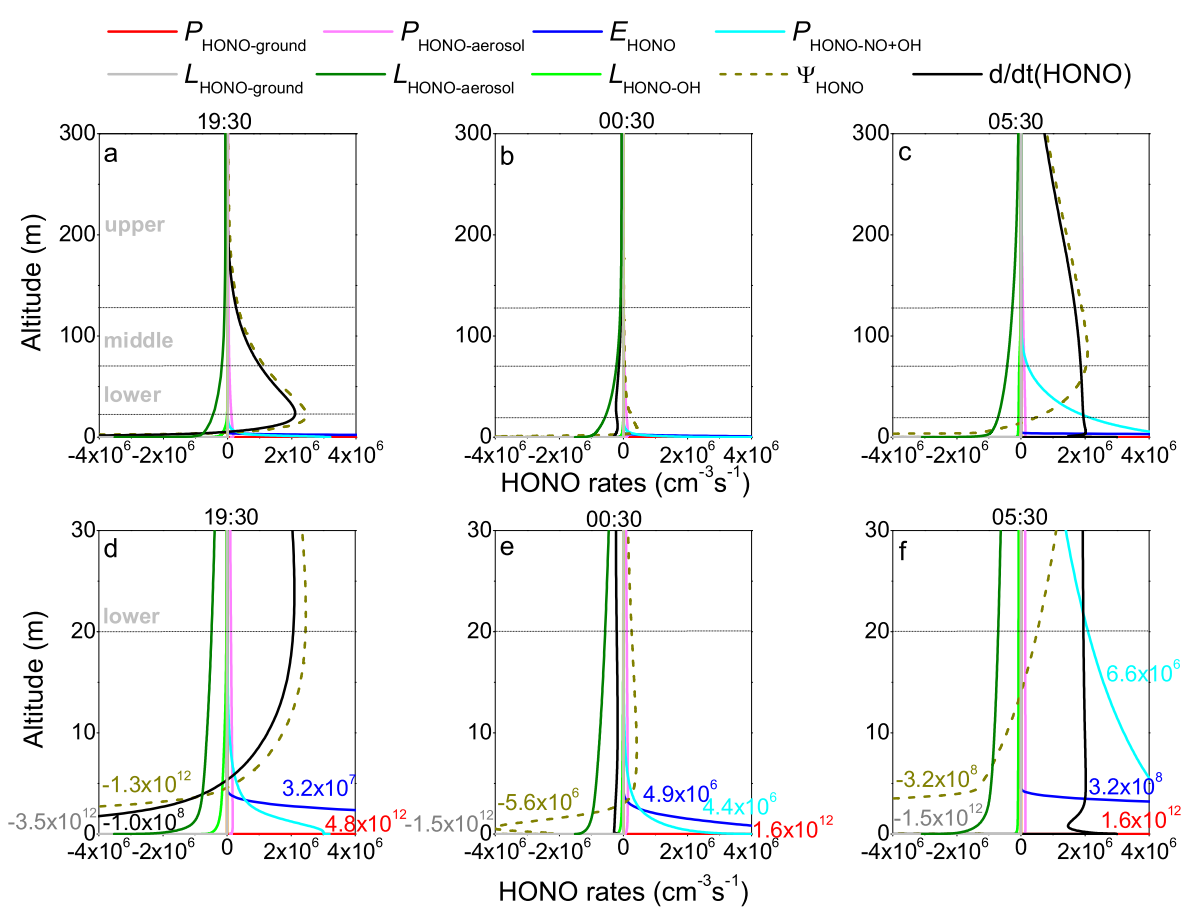

Fig. 9. Modeled vertical profiles of HONO rates at 19:30 CST (a, d), 00:30 CST (b, e) and 05:30 CST (c, f) during the night of 1-2 September 2006. Panels (a), (b), and (c) show the lower $300 \mathrm{~m}$ of the atmosphere. Panels (d), (e), and (f) provide a closer view of the lowest $30 \mathrm{~m}$ of the atmosphere. Numbers in these panels apply to the maxima of the respective processes in the lowest meter above the ground.

Table 3. Integrated HONO production and loss over the lowest $300 \mathrm{~m}$ throughout the nights of the modeling periods, 1-2 and 7-8 September 2006. Percentage contributions of each process are also shown.

\begin{tabular}{|c|c|c|c|c|c|c|c|c|c|c|c|c|}
\hline \multirow[b]{2}{*}{ Periods } & \multicolumn{6}{|c|}{ Production } & \multicolumn{5}{|c|}{ Loss } & \multirow[b]{2}{*}{$\begin{array}{l}\text { Net } \\
\text { Prod. } \\
{\left[\mathrm{cm}^{-2}\right]}\end{array}$} \\
\hline & $\begin{array}{l}\text { Ground } \\
{[\%]}\end{array}$ & $\begin{array}{l}\text { Aerosol } \\
{[\%]}\end{array}$ & $\begin{array}{l}\text { Emiss. } \\
{[\%]}\end{array}$ & $\begin{array}{l}\mathrm{NO} \\
\mathrm{OH} \\
{[\%]}\end{array}$ & + & $\begin{array}{l}\text { Total } \\
{\left[\mathrm{cm}^{-2}\right]}\end{array}$ & $\begin{array}{l}\text { Ground } \\
{[\%]}\end{array}$ & $\begin{array}{l}\text { Aerosol } \\
{[\%]}\end{array}$ & $\begin{array}{l}\text { HONO } \\
+\mathrm{OH} \\
{[\%]}\end{array}$ & $\begin{array}{l}\text { Vert. } \\
\text { Trans. } \\
{[\%]}\end{array}$ & $\begin{array}{l}\text { Total } \\
{\left[\mathrm{cm}^{-2}\right]}\end{array}$ & \\
\hline 1-2 Sep & 74 & 3 & 17 & 6 & & $1.7 \times 10^{15}$ & 71 & 18 & 1 & 10 & $1.4 \times 10^{15}$ & $2.7 \times 10^{14}$ \\
\hline 7-8 Sep & 65 & 3 & 21 & 12 & & $1.8 \times 10^{15}$ & 76 & 18 & 1 & 5 & $1.3 \times 10^{15}$ & $5.3 \times 10^{14}$ \\
\hline
\end{tabular}

$8 \%$ uncertainty in $\mathrm{HONO}$ loss due to reaction with $\mathrm{OH}$ and $<v 1 \%$ uncertainty in other formation and loss process. Because these processes are relatively small, these lead to only $1 \%$ and $4 \%$ uncertainty in total integrated HONO formation and removal, respectively.

\subsection{Dependence of net HONO formation at the ground on vertical stability and emission}

As proposed in Stutz et al. $(2002,2004 \mathrm{a})$ the $\mathrm{HONO} / \mathrm{NO}_{2}$ system tends towards reaching a pseudo steady state (PSS) between HONO formation and loss. One would expect that in our case the air close to the ground was in this PSS. Our model analysis, however, identified the ground as a net source of HONO during the majority of time. Consequently, the system, and in particular the lowest box of our model was shifted away from the pseudo steady state by vertical mixing processes. One can thus expect that vertical mixing and emission both modulate the $\mathrm{HONO}$ to $\mathrm{NO}_{2}$ ratio at the ground, HONO chemistry at the ground, and as a consequence also the integrated net HONO formation in the NBL.

Vertical mixing plays two roles for HONO chemistry at the ground. It controls the amount of $\mathrm{NO}_{2}$ available for making $\mathrm{HONO}$ at the ground and transports newly formed HONO upwards, away from the ground thus affecting HONO ground deposition. For example, weaker vertical mixing in the NBL can lead to larger $\mathrm{NO}_{2}$ and $\mathrm{HONO}$ at the ground and consequently HONO formation and deposition at the ground (Fig. 10). Sensitivity model runs with constant emission show that the impact of vertical mixing on net HONO 


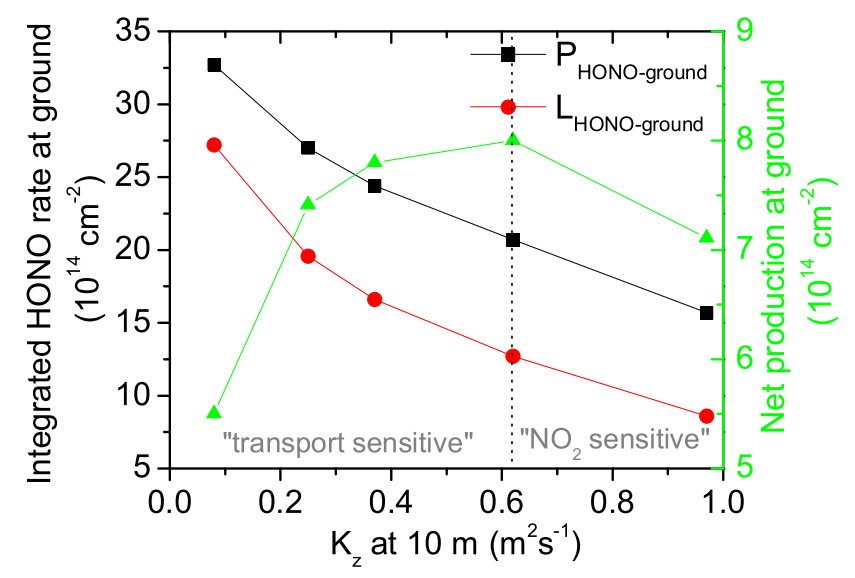

Fig. 10. Sensitivity of integrated HONO formation and loss rates throughout the night at the ground with stability. Eddy diffusivity at $10 \mathrm{~m}$ is plotted as a measure of vertical stability.

formation can be categorized into two regimes, "transport sensitive" and " $\mathrm{NO}_{2}$ sensitive". The "transport sensitive" regime occurs when vertical mixing is weak (in this case when $K_{z}$ at $10 \mathrm{~m}$ is less than $0.6 \mathrm{~m}^{2} / \mathrm{s}$ ) (Fig. 10). During this regime, when vertical mixing becomes stronger, the net formation at the ground increases because vertical mixing transports HONO upward more efficiently leading to a greater decrease in deposition at the ground. This effect outweighs the simultaneous decrease of both $\mathrm{NO}_{2}$ and thus HONO formation at the ground due to mixing of $\mathrm{NO}_{2}$ into larger volumes. On the other hand, the " $\mathrm{NO}_{2}$ sensitive" regime occurs when vertical mixing is efficient (in this case when $K_{z}$ at $10 \mathrm{~m}$ is greater than $0.6 \mathrm{~m}^{2} / \mathrm{s}$ ) and the reduction of HONO production due to decreased levels of $\mathrm{NO}_{2}$ is more substantial than the decrease of HONO deposition due to larger transport. Therefore net HONO production decreases in this regime, i.e. when vertical mixing is stronger.

Sensitivity runs were also carried out to test the effect of the emission strength of $\mathrm{NO}_{\mathrm{x}}$ and HONO on HONO chemistry at the ground. Under the condition of constant nocturnal vertical mixing, when the emission is increased, the model shows an increase of both HONO formation and removal at the ground due to the increase of both HONO and $\mathrm{NO}_{2}$, which leads to an increase of net HONO production at the ground. The opposite is true when emission decreases. Therefore, addition of HONO by direct emission leads to larger net $\mathrm{HONO}$ formation at the ground when vertical mixing is constant.

\section{Conclusions}

During two weeks of the TRAMP 2006 experiment in Houston, TX, (1-14 September, 2006) nocturnal vertical concentration gradients of $\mathrm{HONO}, \mathrm{NO}_{2}$ and $\mathrm{O}_{3}$ were frequently ob- served by the LP-DOAS. HONO developed negative gradients with larger concentrations near the ground and smaller aloft. Maximum HONO mixing ratios of above $2 \mathrm{ppb}$ were observed in the lower height interval (average $20-70 \mathrm{~m}$ ) in the late night, while HONO was often below $100 \mathrm{ppt}$ in the upper height interval (130-300 m). These observations thus indicate that care has to be taken in interpreting surface observations of HONO, as they are not representative for the entire nocturnal boundary layer.

Three nights (1-2, 7-8 and 11-12 September) were selected to perform modeling studies and compare to the observations. Our vertically highly resolved 1-D chemistry and transport model (RCAT 8.2) together with the parameterization of $\mathrm{NO}_{2}$ to $\mathrm{HONO}$ conversion and HONO loss rate at the ground (Trick, 2004) reproduced the observed vertical concentration profiles of $\mathrm{HONO}, \mathrm{NO}_{2}$ and $\mathrm{O}_{3}$. However, the modeled $\mathrm{HONO} / \mathrm{NO}_{2}$ in the middle $(70-130 \mathrm{~m})$ and upper $(130-300 \mathrm{~m})$ height intervals was substantially larger than the observations, resulting in an increase of $\mathrm{HONO} / \mathrm{NO}_{2}$ with altitude in the model, that was not observed in the atmosphere. Analysis of HONO chemistry in the model indicated that the uptake coefficients of HONO were too small on aerosol and too large on the ground. Refined model runs with 10 times larger HONO aerosol uptake $\left(10^{-3}\right)$ and 5 times smaller ground uptake $\left(2 \times 10^{-5}\right)$ showed a much better agreement of $\mathrm{HONO} / \mathrm{NO}_{2}$ with observations for 1-2 and 7-8 September. Better laboratory HONO uptake data is needed to confirm the validity of these uptake coefficients on urban surfaces and aerosol.

The HONO mixing ratios at lower and middle altitude intervals from the refined model showed very good agreement with the observations for 1-2 and 7-8 September, except during the morning rush hour. The greater $\mathrm{HONO} / \mathrm{NO}_{2}$ observed during morning rush hour was most likely due to additional conversion from $\mathrm{HNO}_{3}$ on organic aerosol, as proposed by Ziemba et al. (2010), which is currently not included in our model. It is also possible that the HONO to $\mathrm{NO}_{\mathrm{x}}$ emission ratio varied throughout the night due to changes in vehicle fleet composition. Since there was insufficient information on fleet composition and vehicle type specific $\mathrm{HONO} / \mathrm{NO}_{\mathrm{x}}$ emission ratios, sensitivity runs were performed to study the effect of a possible change in emission ratios. Varying the $\mathrm{HONO} / \mathrm{NO}_{\mathrm{x}}$ emission ratios by $\pm 0.5 \%$ from the original value of $0.8 \%$, i.e. to $0.3 \%$ and $1.3 \%$, led to a $20 \%$ change in $\mathrm{HONO}$ mixing ratios and $\mathrm{HONO} / \mathrm{NO}_{2}$ ratios in all three height intervals during the rush hour period. During the rest of the night, HONO mixing ratios in the lower height interval varied by $13-19 \%$, and by $13 \%$ and $4 \%$ in the middle and upper height intervals, respectively. The higher emission ratios could explain the rush hour HONO on 7-8 September but were still too low to explain the rush hour observations on 1-2 and 11-12 September. As a $\mathrm{HONO} / \mathrm{NO}_{x}$ emission rate of $1.3 \%$ is higher than any published value (see for example (Kurtenbach et al., 2001; Kirchstetter et al., 1996)) we conclude that direct HONO traffic emissions were 
most likely not the explanation for the unexplained rush hour HONO. The model was not capable of capturing the unusual behavior of HONO for 11-12 September, which was most likely caused by precipitation in this night significantly changing HONO formation and/or loss.

Vertical profiles of modeled HONO rates of the two periods (1-2 and 7-8 September) showed that $\mathrm{NO}_{2}$ conversion on the ground was the largest source of HONO (65-74\%), followed by emission (17-21\%). $\mathrm{NO}_{2}$ conversion on aerosol did not play a significant role in HONO formation in our model. On the other hand, deposition at the ground was also the major sink of HONO (71-76\%), followed by uptake on aerosol (18\%). In our modeling studies, the ground acted as both the largest source and sink of HONO in the NBL through $\mathrm{NO}_{2}$ conversion and HONO deposition. There was a net production of $\mathrm{HONO}$ at the ground throughout the three modeling periods. Vertical transport played the dominant role as the source of HONO aloft. Sensitivity studies showed that HONO formation at the ground can be modulated by both vertical mixing and emission. In the stable NBL, net HONO production increases with stronger vertical mixing and stronger emission.

\section{Supplement related to this article is available online at: http://www.atmos-chem-phys.net/11/3595/2011/ acp-11-3595-2011-supplement.pdf.}

Acknowledgements. This study was supported by a Career Award from the National Science Foundation Atmospheric Chemistry Program (ATM-0348674), the Texas Environmental Research Consortium, and the Houston Advanced Research Center (Grants $\mathrm{H} 78, \mathrm{H} 86$, and $\mathrm{H} 104 \mathrm{C})$.

Edited by: A. Hofzumahaus

\section{References}

Acker, K., Moller, D., Wieprecht, W., Meixner, F., Bohn, B., Gilge, S., Plass-Dulmer, C., and Berresheim, H.: Strong daytime production of $\mathrm{OH}$ from $\mathrm{HNO}_{2}$ at a rural mountain site, Geophys. Res. Lett., 33, L02809, doi:10.1029/2005GL024643, 2006.

Alicke, B., Platt, U., and Stutz, J.: Impact of nitrous acid photolysis on the total hydroxyl radical budget during the Limitation of Oxidant Production/Pianura Padana Produzione di Ozono study in Milan, J. Geophys. Res., 107, 8196, doi:10.1029/2000JD000075, 2002.

Ammann, M., Rossler, E., Strekowski, R., and George, C.: Nitrogen dioxide multiphase chemistry: Uptake kinetics on aqueous solutions containing phenolic compounds, Phys. Chem. Chem. Phys., 7, 2513-2518, 2005.

Arens, F., Gutzwiller, L., Baltensperger, U., Gaggeler, H., and Ammann, M.: Heterogeneous reaction of $\mathrm{NO}_{2}$ on diesel soot particles, Environ. Sci. Technol., 35, 2191-2199, 2001.

Aumont, B., Chervier, F., and Laval, S.: Contribution of HONO sources to the $\mathrm{NO}_{\mathrm{x}} / \mathrm{HO}_{\mathrm{x}} / \mathrm{O}_{3}$ chemistry in the polluted boundary layer, Atmos. Environ., 37, 487-498, 2003.
Businger, J., Wyngaard, J., Izumi, Y., and Bradley, E.: Flux-profile relationships in atmospheric surface layer, J. Atmos. Sci., 28, 181-189, 1971.

Calvert, J., Yarwood, G., and Dunker, A.: An evalutation of the mechanism of nitrous-acid formation in the urban atmosphere, Res. Chem. Intermediat., 20, 463-502, 1994.

Day, B. M., Rappenglück, B., Clements, C. B., Tucker, S. C., and Brewer, W. A.: Nocturnal boundary layer characteristics and land breeze development in Houston, Texas during TexAQS II, Atmos. Environ., 44, 4014-4023, doi:10.1016/j.atmosenv.2009.01.031, 2010.

Finlayson-Pitts, B. J. and Pitts, J. N.: Chemistry of the upper and lower atmosphere, Academic Press, San Diego, CA, USA, 1969, 2000.

Finlayson-Pitts, B., Wingen, L., Sumner, A., Syomin, D., and Ramazan, K.: The heterogeneous hydrolysis of $\mathrm{NO}_{2}$ in laboratory systems and in outdoor and indoor atmospheres: An integrated mechanism, Phys. Chem. Chem. Phys., 5, 223-242, doi:10.1039/b208564j, 2003.

Fuchs, N. A. and Sutugin, A. G.: Highly dispersed aerosols, Ann Arbor Science, Ann Arbor, MI, USA, 1-90, 1971.

George, C., Strekowski, R., Kleffmann, J., Stemmler, K., and Ammann, M.: Photoenhanced uptake of gaseous $\mathrm{NO}_{2}$ on solidorganic compounds: a photochemical source of HONO?, Faraday Discuss., 130, 195-210, doi:10.1039/b417888m, 2005.

Geyer, A. and Stutz, J.: Vertical profiles of $\mathrm{NO}_{3}, \mathrm{~N}_{2} \mathrm{O}_{5}, \mathrm{O}_{3}$, and $\mathrm{NO}_{\mathrm{x}}$ in the nocturnal boundary layer: 2. Model studies on the altitude dependence of composition and chemistry, J. Geophys. Res., 109, D16398, doi:10.1029/2003JD004211, 2004a.

Geyer, A. and Stutz, J.: The vertical structure of $\mathrm{OH}-\mathrm{HO}_{2}-$ $\mathrm{RO}_{2}$ chemistry in the nocturnal boundary layer: A onedimensional model study, J. Geophys. Res., 109, D16301, doi:10.1029/2003JD004425, 2004b.

Gutzwiller, L., Arens, F., Baltensperger, U., Gaggeler, H., and Ammann, M.: Significance of semivolatile diesel exhaust organics for secondary HONO formation, Environ. Sci. Technol., 36, 677-682, doi:10.1021/es015673b, 2002.

Harrison, R. and Collins, G.: Measurements of reaction coefficients of $\mathrm{NO}_{2}$ and $\mathrm{HONO}$ on aerosol particles, J. Atmos. Chem., 30, 397-406, 1998.

Kalberer, M., Ammann, M., Arens, F., Gaggeler, H., and Baltensperger, U.: Heterogeneous formation of nitrous acid (HONO) on soot aerosol particles, J. Geophys. Res., 104, 1382513832, 1999.

Kessler, C. and Platt, U.: Nitrous acid in polluted air masses - Sources and formation pathways, in: Physico-chemical Behaviour of Atmospheric Pollutants (Proceedings), edited by: Versino, B. and Angeletti, G., D. Reidel, Dordrecht, The Netherlands, 412-422, 1984.

Kirchstetter, T., Harley, R., and Littlejohn, D.: Measurement of nitrous acid in motor vehicle exhaust, Environ. Sci. Technol., 30, 2843-2849, 1996.

Kleffmann, J. and Wiesen, P.: Heterogeneous conversion of $\mathrm{NO}_{2}$ and $\mathrm{NO}$ on $\mathrm{HNO}_{3}$ treated soot surfaces: atmospheric implications, Atmos. Chem. Phys., 5, 77-83, doi:10.5194/acp-5-772005, 2005.

Kleffmann, J., Kurtenbach, R., Lorzer, J., Wiesen, P., Kalthoff, N., Vogel, B., and Vogel, H.: Measured and simulated vertical profiles of nitrous acid - Part I: Field measurements, Atmos. 
Environ., 37, 2949-2955, doi:10.1016/S1352-2310(03)00242-5, 2003.

Kleffmann, J., Benter, T., and Wiesen, P.: Heterogeneous reaction of nitric acid with nitric oxide on glass surfaces under simulated atmospheric conditions, J. Phys. Chem. A, 108, 5793-5799, doi:10.1021/jp040184u, 2004.

Kleffmann, J., Gavriloaiei, T., Hofzumahaus, A., Holland, F., Koppmann, R., Rupp, L., Schlosser, E., Siese, M., and Wahner, A.: Daytime formation of nitrous acid: A major source of $\mathrm{OH}$ radicals in a forest, Geophys. Res. Lett., 32, L05818, doi:10.1029/2005GL022524, 2005.

Kleffmann, J., Lorzer, J., Wiesen, P., Kern, C., Trick, S., Volkamer, R., Rodenas, M., and Wirtz, K.: Intercomparison of the DOAS and LOPAP techniques for the detection of nitrous acid (HONO), Atmos. Environ., 40, 3640-3652, doi:10.1016/j.atmosenv.2006.03.027, 2006.

Kurtenbach, R., Becker, K., Gomes, J., Kleffmann, J., Lorzer, J., Spittler, M., Wiesen, P., Ackermann, R., Geyer, A., and Platt, U.: Investigations of emissions and heterogeneous formation of HONO in a road traffic tunnel, Atmos. Environ., 35, 3385-3394, 2001.

Kurtenbach, R., Ackermann, R., Becker, K., Geyer, A., Gomes, J., Lorzer, J., Platt, U., and Wiesen, P.: Verification of the contribution of vehicular traffic to the total NMVOC emissions in Germany and the importance of the $\mathrm{NO}_{3}$ chemistry in the city air, J. Atmos. Chem., 42, 395-411, 2002.

Lammel, G. and Cape, J.: Nitrous acid and nitrite in the atmosphere, Chem. Soc. Rev., 25, 361-369, 1996.

Lefer, B. and Rappenglück, B.: The TexAQS-II radical and aerosol measurement project (TRAMP) Preface, Atmos. Environ., 44, 3997-4004, doi:10.1016/j.atmosenv.2010.05.053, 2010.

Lefer, B., Rappenglück, B., Flynn, J., and Haman, C.: Photochemical and meteorological relationships during the Texas-II Radical and Aerosol Measurement Project (TRAMP), Atmos. Environ., 44, 4005-4013, doi:10.1016/j.atmosenv.2010.03.011, 2010.

Leuchner, M. and Rappenglück, B.: VOC source-receptor relationships in Houston during TexAQS-II, Atmos. Environ., 44, 40564067, doi:10.1016/j.atmosenv.2009.02.029, 2010.

Li, S., Matthews, J., and Sinha, A.: Atmospheric hydroxyl radical production from electronically excited $\mathrm{NO}_{2}$ and $\mathrm{H}_{2} \mathrm{O}$, Science, 319, 1657-1660, doi:10.1126/science.1151443, 2008.

Pitts, J., Biermann, H., Winer, A., and Tuazon, E.: Spectroscopic identification and measurement of gaseous nitrous-acid in dilute auto exhaust, Atmos. Environ., 18, 847-854, 1984.

Platt, U.: The origin of nitrous and nitric acid in the atmosphere, in: Chemistry of Multiphase Atmospheric Systems, edited by: Jaeschke, W., Springer, New York, USA, 229-319, 1985.

Platt, U. and Stutz, J.: Differential Optical Absorption Spectroscopy: Principles and Applications, Springer, Berlin, Heidelberg, Germany, 1-597, doi:10.1007/978-3-540-75776-4, 2008.

Saliba, N., Yang, H., and Finlayson-Pitts, B.: Reaction of gaseous nitric oxide with nitric acid on silica surfaces in the presence of water at room temperature, J. Phys. Chem. A, 105, 10339-10346, doi:10.1021/jp012330r, 2001.

Stemmler, K., Ammann, M., Donders, C., Kleffmann, J., and George, C.: Photosensitized reduction of nitrogen dioxide on humic acid as a source of nitrous acid, Nature, 440, 195-198, doi:10.1038/nature04603, 2006.

Stockwell, W., Kirchner, F., Kuhn, M., and Seefeld, S.: A new mechanism for regional atmospheric chemistry modeling, $\mathrm{J}$ Geophys. Res., 102, 25847-25879, 1997.

Stutz, J. and Platt, U.: Numerical analysis and estimation of the statistical error of differential optical absorption spectroscopy measurements with least-squares methods, Appl. Opt., 35, 60416053, 1996.

Stutz, J., Alicke, B., and Neftel, A.: Nitrous acid formation in the urban atmosphere: Gradient measurements of $\mathrm{NO}_{2}$ and HONO over grass in Milan, Italy, J. Geophys. Res., 107, 8192, doi:10.1029/2001JD000390, 2002.

Stutz, J., Alicke, B., Ackermann, R., Geyer, A., Wang, S., White, A., Williams, E., Spicer, C., and Fast, J.: Relative humidity dependence of HONO chemistry in urban areas, J. Geophys. Res., 109, D03307, doi:10.1029/2003JD004135, 2004a.

Stutz, J., Alicke, B., Ackermann, R., Geyer, A., White, A., and Williams, E.: Vertical profiles of $\mathrm{NO}_{3}, \mathrm{~N}_{2} \mathrm{O}_{5}, \mathrm{O}_{3}$, and $\mathrm{NO}_{x}$ in the nocturnal boundary layer: 1. Observations during the Texas Air Quality Study 2000, J. Geophys. Res., 109, D16398, doi:10.1029/2004JD005216, 2004b.

Stutz, J., Oh, H.-J., Whitlow, S. I., Anderson, C., Dibbb, J. E., Flynn, J. H., Rappenglück, B., and Lefer, B.: Simultaneous DOAS and mist-chamber IC measurements of HONO in Houston, TX, Atmos. Environ., 44, 4090-4098, doi:10.1016/j.atmosenv.2009.02.003, 2010a.

Stutz, J., Wong, K. W., Lawrence, L., Ziemba, L., Flynn, J. H., Rappenglück, B., and Lefer, B.: Nocturnal $\mathrm{NO}_{3}$ radical chemistry in Houston, TX, Atmos. Environ., 44, 4099-4106, doi:10.1016/j.atmosenv.2009.03.004, 2010b.

Trick, S.: Formation of nitrous acid on urban surfaces - a physicalchemical perspective, Ph.D. thesis, University of Heidelberg, Heidelberg, Germany, 2004.

Voigt, S., Orphal, J., Bogumil, K., and Burrows, J. P.: The temperature dependence (203-293 K) of the absorption cross sections of $\mathrm{O}_{3}$ in the $230-850 \mathrm{~nm}$ region measured by Fouriertransform spectroscopy, J. Photochem. Photobiol. A, 143, 1-9, doi:10.1016/S1010-6030(01)00480-4, 2001.

Voigt, S., Orphal, J., and Burrows, J.: The temperature and pressure dependence of the absorption cross-sections of $\mathrm{NO}_{2}$ in the 250 $800 \mathrm{~nm}$ region measured by Fourier-transform spectroscopy, J. Photochem. Photobiol. A, 149, 1-7, 2002.

Wang, S., Ackermann, R., and Stutz, J.: Vertical profiles of $\mathrm{O}_{3}$ and $\mathrm{NO}_{\mathrm{x}}$ chemistry in the polluted nocturnal boundary layer in Phoenix, AZ: I. Field observations by long-path DOAS, Atmos. Chem. Phys., 6, 2671-2693, doi:10.5194/acp-6-2671-2006, 2006.

Wong, K. W. and Stutz, J.: Influence of nocturnal vertical stability on daytime chemistry: A one-dimensional model study, Atmos. Environ., 44, 3753-3760, doi:10.1016/j.atmosenv.2010.06.057, 2010.

Yu, Y., Galle, B., Panday, A., Hodson, E., Prinn, R., and Wang, S.: Observations of high rates of $\mathrm{NO}_{2}-\mathrm{HONO}$ conversion in the nocturnal atmospheric boundary layer in Kathmandu, Nepal, Atmos. Chem. Phys., 9, 6401-6415, doi:10.5194/acp-9-6401-2009, 2009.

Ziemba, L. D., Dibb, J. E., Griffin, R. J., Anderson, C. H., Whitlow, S. I., Lefer, B. L., Rappenglück, B., and Flynn, J.: Heterogeneous conversion of nitric acid to nitrous acid on the surface of primary organic aerosol in an urban atmosphere, Atmos. Environ., 44, 4081-4089, doi:10.1016/j.atmosenv.2008.12.024, 2010. 